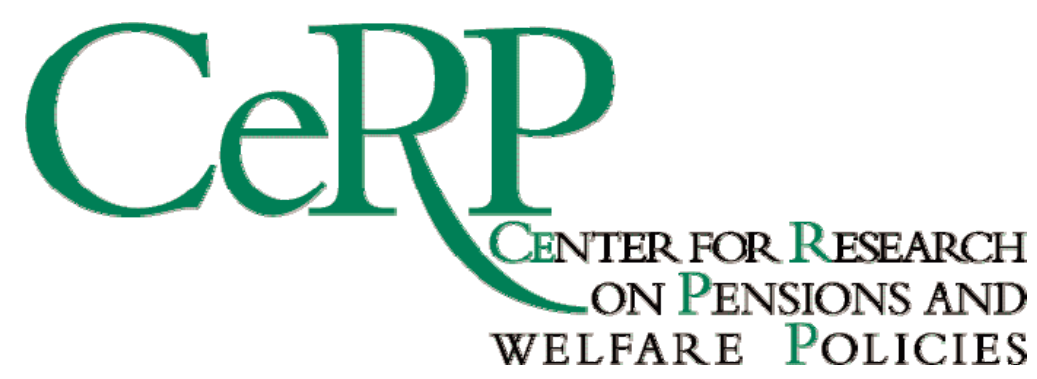

Working Paper 124/11

\title{
SHOULD WE RETIRE EARLIER IN ORDER TO LOOK AFTER OUR PARENTS? THE ROLE OF IMMIGRANTS
}

Agnese Romiti

Mariacristina Rossi 


\title{
Should we Retire Earlier in order to Look After our Parents? The Role of immigrants*
}

\author{
Agnese Romiti ${ }^{\dagger} \quad$ Mariacristina Rossi $i^{\ddagger}$
}

November 2011

\begin{abstract}
This paper aims to detect whether or not people could work for more years in the presence of a more flourishing and cheaper formal care market, which, in turn, would provide support for people who are still at work and who have to cope with the care of their elderly parents and relatives. We focus on the flow of immigrants as a key variable in order to detect whether or not this channel is at work. We disentangle retirement decisions, first by modelling retirement choice using a simple life-cycle framework in which caring for parents is introduced into the choice set. We then correlate retirement choice with the gap between the foregone salary if early retirement is chosen and the price of formal care. The findings show that immigrants contribute to the postponement of retirement for women only.

According to our estimates, we predict that the increase in immigration rate (equal to 4 percentage points) which occurred over the period 2000-2008 raised the retirement age for Italian women (with parents who are still alive) by almost one year, while the impact on men was non-existent.
\end{abstract}

Keywords: Retirement decisions, life cycle, option value, international migration, long-term care.

JEL codes: J22, J26, F22.

${ }^{*}$ We would like to thank Flavia Coda Moscarola, Franco Peracchi, and Giovanni Peri for very helpful comments and discussions. We are grateful for comments and suggestions to participants at the 9th International Workshop on Pension, Insurance and Saving - Dauphine University, AIEL, EALE, SMYE, and TEMPO.

†Email: agnese.romiti@carloalberto.org. Tor Vergata University and CeRP - Collegio Carlo Alberto.

${ }_{\ddagger}^{\ddagger}$ Email: rossi@econ.unito.it. University of Turin and CeRP - Collegio Carlo Alberto. 


\section{Introduction}

In OECD countries, generous pension policy schemes, particularly those which existed during the 1980s and early 1990s, have been advocated as being responsible for the early retirement of workers from the labour force. Italy stands out among the OECD countries as having the highest pension deficit: in 2008, it was $14.1 \%$ of GDP compared to the OECD average of $7 \%$, and increased by $23 \%$ over the period 1995-2005 (OECD). The Italian pension system is designed on a pay-as-you-go (PAYG) basis; older workers still receive their pensions under the defined benefit (DB) scheme, whereas the shift to the notional defined contribution (NDC) scheme will affect younger generations. The structure of this pension system gives little incentive to work for longer, as pension benefits are weakly related to the worker's contribution history. Older workers might be induced to take early retirement, as the difference between their salary and their pension is not enough to justify remaining in work. The disincentive to work into old age is exacerbating the financial burden on the pension debt, due to the ageing population. Italy is one of the oldest populations among the OECD countries, second only to Japan, with people aged 65 representing $33 \%$ of the working-age population, compared to an average of $23.6 \%$ for the OECD countries (OECD, 2010). Figure 1 plots the old age dependency ratio ${ }^{1}$, which reached $31 \%$ in 2010 following a steady upward trend. This pattern has been fostered by a constant low total fertility rate (Boeri et al., 2005), which was between 1.25 and 1.41 over the period 2001-2010 (ISTAT).

There is a vast body of literature documenting how strong disincentives to continue working into old age are at work in many OECD countries: Belloni and Alessie (2009, 2010), Brugiavini (1999), and Brugiavini and Peracchi (2003, 2004) provide evidence for this phenomenon in Italy, whereas Gruber and Wise (2004) provide evidence from 12 OECD countries. The main framework utilized for estimating how incentives and disincentives work with regard to retirement decisions is the option value (OV) model Stock and Wise, 1990. According to this model, each year, individuals compare the expected utility of current retirement to the maximum utility corresponding to retiring at any future date. The OV is defined as the difference between the utility corresponding to immediate retirement and that of postponing retirement. The agent will rationally choose the option that guarantees a higher level of utility, therefore the OV of postponing retirement will be negative for those choosing immediate retirement. The general aim of the aforementioned papers is to estimate the effectiveness of a set of incentives/disincentives (such as a change in pension policy) on the decision to postpone retirement.

Our paper examines an innovative and unexplored question: is the implicit disincentive to continue working affected by the change in the shadow cost of continuing work, which can be summarised as the cost of household chores bought in the market and the

\footnotetext{
${ }^{1}$ Computed using registry data from the National Institute of Statistics (ISTAT) and defined as the ratio between the population aged 65 and older and the working-age population (15-64): it was $22 \%$ in 1992 and reached $30.5 \%$ in 2009.
} 
cost of care for elderly parents? In a country such as Italy, where familial bonds form close links between children and their parents, the rapidly ageing population, accompanied by an almost non-existent care market, has imposed the dramatic problem of caring for the elderly upon their children, who are, ultimately, the first responsible for their parents. Italy has the highest dependency ratio in Europe, with the population ageing at an unprecedented pace. In spite of this demographic trend, little has been done to develop a formal market for elderly care and the provision of in-kind long-term care is scarce and inadequate. Residential care covers only $3 \%$ of those aged 65 and over, whereas home care covers only three out of 1000 people aged 65 and over ${ }^{2}$. In addition, institutions for the elderly are perceived as being of very low quality and inferior to having the parent living with the child or buying the services of a caregiver who lives at home with the elderly person. The price of care is, therefore, pivotal in the decision as to whether or not to buy care for elderly relatives, which has been provided in the past by the young women within the family. Broad empirical evidence has reported that the care for parents inevitably affects working and retirement decisions (Bolin et al., 2008; Kolodinsky and Shirey, 2000; Wolf and Soldo, 1994) and particularly those of women in Italy (Marenzi and Pagani, 2008), given their traditional role as caregivers (Lamura et al., 2008). We argue that the recent boost in immigration and the contribution of immigrants to enlarging the size of the household services sector (formal long-term care and household chores) and to reducing its market cost have increased the opportunity cost of early retirement, by making the cost of formal care more affordable.

Italy has witnessed a massive increase in the number of immigrants, nowadays reaching over $7 \%$ of the total population. Immigration has been characterised by inflows of caregivers and people who are mainly employed in household services, which has had an impressive role in fulfilling the unsatisfied demand for care and, in general, of services relating to housekeeping activities.

To our knowledge, the role of immigration as a key factor in explaining retirement decisions has not yet been analysed. Our aim is to fill this gap.

The rest of the paper is laid out as follows. Section 2 introduces the immigration phenomenon and the institutional setting of the pension system in Italy. Section 3 provides a review of the relevant literature (3.1) and describes the theoretical model (3.2). Section 4 presents the empirical strategy which was adopted. Section 5 describes the data used and Section 6 discusses the results obtained. Finally, the paper concludes with a few remarks in Section 7.

\footnotetext{
${ }^{2}$ L'assistenza agli anziani non autosufficienti in Italia $2^{\circ}$ Rapporto (2010).
} 


\section{Immigration and the institutional setting in Italy}

Immigration to Italy is a fairly recent and steadily increasing phenomenon. In 1991, resident immigrants represented only $0.6 \%$ of the total resident population, but in 2010 , there were over four million, corresponding to $7 \%$ of the total population (ISTAT). Figure 2 plots the trend in the immigration rate of resident immigrants over the period 20002009, disaggregated by macro-areas of origin. The upward trend is clearly shared by all groups of countries but it is mainly driven by the Eastern European component, which represents the $92 \%$ of the immigrants coming from Europe and accounts for $3.5 \%$ of the total resident population, according to the latest data available for 2009. The role played by immigrants in enhancing the size of the household services sector is clearly shown by Table 1 and Figure 3, which report the incidence of immigrants in the domestic sector over the period 2000-2008, taking into account only workers registered to the Italian National Social Security Institute (INPS). Table 1 reports the proportion of workers employed in the domestic sector by immigration status. The share of immigrants out of the workers employed in the household services sector has been increasing steadily: they represented $51 \%$ of the total number of employees in this sector in 2000 and exceeded $78 \%$ in 2008 . On top of that, these percentages are an underestimation of the actual contribution of immigrants, as the vast majority of immigrants employed in this sector are not registered to the INPS, since they do not have a regular contract.

This evidence suggests that the recent large inflow of low-skilled immigrants to Italy, by massively enlarging the magnitude of the long-term care market and pushing down its cost, may have played a role in shaping retirement decisions by increasing the opportunity cost of early retirement for natives. Our study detects whether or not workers could work for longer with a more flourishing and cheaper formal care market, using the flow of immigrants as the price of care.

Retirement often coincides with parents getting older and requiring assistance. The minimum retirement age in Italy was very low until the reforms that took place in the 1990s (Amato, Dini and Prodi's reforms), which made the rules for retirement more restrictive. The financial un-sustainability of the pension system imposed an increase in the retirement age and a decrease in the pension benefits. Until the aforementioned reforms, the incentive to remain in work was very small (if not non-existent), as pension benefits were practically uncorrelated with the amount of contributions paid (Fornero and Sestito, 2005). In addition, the presence of elderly parents might exacerbate the disincentive to work, as the price of buying care in the market can be a strong deterrent to work. Women, in a traditional country such as Italy, are usually the caregivers in the family, therefore their early retirement can be associated with the need to care for others within the family. As a consequence the price of care, which immigrants have shaped over time, may play a pivotal role in creating an incentive to retire later for them. The empirical evidence provided by the Bank of Italy's Survey on Household Income and Wealth (SHIW) shows that both women and men experienced an increase in their expected 
retirement age over the period of our analysis, as shown in Table 2. Expected retirement age increased by approximately 1.5 year for both women and men. Given this evidence and controlling for the institutional measures which have certainly contributed to this pattern by increasing the minimum retirement age, the research question we want to test is whether or not immigrants play a role in explaining this upward trend and whether this role differs according to gender and between individuals with different degrees of family commitments.

\section{Optimal retirement decision}

\subsection{An overview}

The literature on the determinants of retirement decisions is particularly fertile. The common denominator of most of these studies is the role played by financial incentives. Detecting the effectiveness of policies such as those discouraging retirement through the introduction of a DC scheme rather than a DB scheme is crucial to understanding how incentives to postpone retirement are taken successfully into account in the retirement decision-making process.

Within this body of literature, the paper of Stock and Wise (1990) stands out as the seminal work which explains pension choice according to the OV model. In a nutshell, the OV model considers the different utilities associated with immediate retirement versus postponement and chooses the best of the alternatives. An alternative to the OV model is the dynamic programming approach (French, 2005), which differs from the former only in terms of the way in which uncertainty (which is captured by a stochastic component relative to health status or labour earning, for example) is treated. The OV model has been implemented using both reduced forms and structural approaches. However, the results found using the two different strategies differ very little from each other (e.g., Lumsdaine et al., 1992).

Several papers have drawn on the seminal contribution of Stock and Wise. We quote only some of the most relevant papers to our study. Brugiavini and Peracchi (2003) adopted a reduced form of the OV model and estimated a probit using the administrative data provided by INPS. In order to measure the effectiveness of incentive measures, they used retirement incentives such as the stock of social security wealth (SSW), which they combined with other alternative marginal measures such as social security accrual, the peak value and the $\mathrm{OV}^{3}$. Their findings showed that the SSW had the expected sign and

\footnotetext{
${ }^{3}$ The (one year) accrual for an individual of age a at time $t$ is defined as the difference between the SSW at time t relevant to postponing retirement at age $\mathrm{a}+1$ and the SSW at time $t$ relevant to retirement at age a. The OV model considers the present discounted value of future income corresponding to any future retirement age and then computes the difference between this value for the case of immediate retirement versus this value at the optimal age. The prediction is that a worker will continue working until the OV is positive. This measure entails two components of compensation from working: discounted utility from future wage and the change in the discounted utility of benefits between immediate retirement
} 
was strongly significant, as opposed to the marginal incentive measures which were barely significant and had the opposite sign to what was expected. In a subsequent paper, Brugiavini and Peracchi (2004) estimated a reduced-form probit including as regressors the predicted values of the SSW, different financial incentives, and pensionable earnings. In this case, the incentive variables almost always had the expected sign, whereas the SSW did not have the expected sign in many of the specifications and was often not significant.

Cross-country evidence is represented by the study of Gruber and Wise (2004), who applied the same template to 12 OECD countries by running a reduced form of the OV model (probit regression) and simulating different policy scenarios, provided strong support for the significant causal effect of financial incentives on retirement decisions ${ }^{4}$.

Bottazzi et al. (2006) used our same dataset and extended the analysis of retirement to the use of information about retirement expectations ${ }^{5}$. The authors analysed the effect of perceived financial incentives, such as the SSW, on the wealth accumulation of Italian workers, exploiting the exogenous variation in replacement rate and the change in the eligibility rules introduced by the Dini's pension reform in 1995. They analysed whether or not workers had revised their expectations about replacement rate and retirement age as a consequence of the reform. The evidence, gathered using a difference in differences approach, shows that workers revised their expectations in a direction which was consistent with the reform. Moreover they showed that a crowding-out effect of perceived SSW on individual wealth accumulation occurred for individuals who were well-informed about the pension reforms and to a much lesser extent for less well-informed individuals.

The need for care as requested by elderly parents, exacerbated by the thinness of the care market, may act as a disincentive to continue work. If the increasing life expectancy implies that the elderly will experience more years of disability before their death, then the increase in morbidity resulting from lower mortality rates will add to the demand for caregivers. Workers who are eligible to retire face the trade-off between continuing to work, thereby increasing their SSW, or retiring earlier and accepting a lower level of pension benefits. Retiring earlier also allows older workers with living parents to care for them and to avoid buying long-term care on the formal market. Most of the studies on the role of informal care giving on labour market outcomes use data from the US (Ettner, 1996;

and retiring at the optimal age. This second component of the OV model represents the peak value, an alternative marginal incentive measure proposed by Coile and Gruber (2000) in order to exclude the individual heterogeneity which is linked to wage earnings, as occurs in the OV model. As wage earnings are a proxy for individual preferences as regards working, the peak value allows the impact of financial incentives to be isolated from heterogeneity.

${ }^{4}$ Samwick (1998) represents another relevant study which applies this reduced-form version of the OV model for the case of the US. In a recent paper, Belloni and Alessie (2009) estimated a version of the OV model which accounts for the dynamic self-selection of women using administrative data from the INPS. Their results confirm the importance of incentives for retirement decisions and provide evidence that dynamic self-selection causes the marginal utility of leisure to be underestimated, and thus the effect of pension reforms to be overestimated.

${ }^{5}$ This dataset alone contains information on the expected retirement age and expected replacement rate for each (working) respondent. 
Kolodinsky and Shirey, 2000; Wolf and Soldo, 1994), with fewer cases analysing the UK (Carmichael and Charles, 1998, 2003), a few cross-country studies of European countries (Bolin et al., 2008; Crespo, 2006) and only one study which is relevant to Italy (Marenzi and Pagani, 2008). All of these studies are consistent in pointing out the negative impact of the provision of informal care on different measures of labour market supply, at either the intensive or the extensive margin.

This paper is also closely related to the literature on the impact of immigration on the host country, which is very fertile, particularly with regard to the impact of immigration on labour market outcomes, such as wages and employment. There is a fairly strong agreement that this impact is non-negative or non-significant (Card, 1990, 2001, 2007; D'Amuri et al., 2010; Dustmann et al., 2005; Gavosto et al., 1999; Ottaviano and Peri, 2008, 2011; Peri, 2007), with only a few exceptions in favour of a negative impact (Borjas, 2003; Borjas et al., 2008).

To the best of our knowledge, there are only three studies to date which have investigated the relationship between immigration and native labour supply: Cortès and Tessada (2001) were the first to analyse this question using US data. They provided evidence to show that low-skilled immigration had affected women at the top quartile of the wage distribution, by increasing the intensive margin of their labour supply, reducing their time spent on household work and increasing their expenditure on housekeeping services. Another example is provided by Farrè et al. (2011), who showed that female immigrants have increased the labour supply of highly-educated women mainly at the intensive margin, in particular they have helped women with younger children or other family commitments, such as co-resident elderly relatives or retired husbands. With regard to Italy, Barone and Mocetti (2011) found similar results, showing that female immigrants who specialised in household production had increased the labour supply of highly-educated Italian women only at the intensive margin. Despite the evidence on labour supply, the retirement decision represents a different choice for workers. On the contrary with respect to the former decision, the latter is an irreversible choice and it involves a different age-bracket of the working age population. To the best of our knowledge, there are no existing studies which aim to investigate the relationship between immigration and retirement decisions.

The main contributions of this paper are both theoretical and empirical. From a theoretical perspective, we are contributing to the existing literature by using inter-temporal optimisation over two dimensions. Firstly, we use an OV type of decisional model in order to find the determinants of the success of incentives to postpone retirement. Allowing for asset accumulation within the model provides us with testable implications of the effect of wealth (other than SSW) on retirement decisions. As far as we know, the role of private wealth accumulation has thus far been neglected in the analysis (with the exception of Chan and Stevens, 2002, 2004). Second, we also take into account the role of care for elderly parents or relatives during retirement.

In addition, we are contributing to the empirical literature on the impact of immi- 
gration on the host country by estimating the role played by immigrants in shaping the retirement choices of workers. As we argue that immigration affects retirement decisions due to its contribution to long-term care and household production, we also aim to find the groups which benefit most from this contribution.

Moreover, this is the first study which takes into account wealth and savings as potential determinants of retirement behaviour using Italian data, despite the empirical evidence of positive discretionary savings at all ages (Brugiavini and Padula, 2001).

\subsection{Theoretical set-up}

We adopt a theoretical model ${ }^{6}$ similar in spirit to Chan and Stevens (2004) who follow the Option value approach pioneered by Stock and Wise (1990), enriching the latter model in order to allow for the role of savings across time periods. We improve upon Chan and Stevens (2004) under two main respects: we introduce the non separability between leisure and consumption and we enrich their model allowing for the role of the long-term care costs related to parental care. As Stock and Wise (1990) and Chan and Stevens (2002, 2004) our model is a modified version of the standard life-cycle approach with a leisure enhancing factor entering the utility function only after retirement. Individuals are assumed to maximize the following inter-temporal and separable utility function, with a Constant Relative Risk Aversion (CRRA) form:

$$
\max _{c t} U\left(c_{t}, c_{t+1}, \ldots, c_{T}\right)=\max _{c_{t}, c_{t+1} . . c_{T}} \sum_{s=t}^{R} \frac{\left(c_{s}\right)^{1-\gamma}}{(1+\rho)^{s-t}(1-\gamma)}+\sum_{s=R+1}^{T} \frac{\left(k c_{s}\right)^{1-\gamma}}{(1+\rho)^{s-t}(1-\gamma)}
$$

where $c$ is consumption level, $1 / \gamma$ is the inter-temporal elasticity of substitution, $\rho$ is the subjective discount rate, $T$ the expected lifetime, and $k>1$ is a factor enhancing utility when individuals enjoy free time. It captures, in other words, the leisure in the utility function which we suppose the individual can enjoy if she/he does neither work nor takes care of her/his parents. $R$ is the age at which individuals retire and $T$ is the end of lifetime (known with certainty).

The inter-temporal budget constraint can be written as follows:

$$
\sum_{s=t}^{T} \frac{c_{s}}{(1+r)^{s-t}}=A_{t}+\sum_{s=t}^{R} \frac{y_{s}}{(1+r)^{s-t}}+\sum_{s=R+1}^{T} \frac{B_{s}}{(1+r)^{s-t}}
$$

where $y$ and $B$ are labour income and pension benefits, respectively, $A_{t}$ is the sum of

\footnotetext{
${ }^{6}$ The analytical description of the theoretical model is reported in the Appendix.
} 
real and financial wealth, and $r$ is the annual interest rate, supposed to be known and constant over time. Uncertainty is removed from the model by assuming that individuals know with certainty their expected end of life.

The maximization problem, assuming $r=\rho$ and equal to zero ${ }^{7}$, yields the following first order conditions:

$$
\begin{array}{ll}
c_{t}=c_{t-1}=c & \text { if } t \neq R+1 \\
c_{R+1}=k^{\frac{1-\gamma}{\gamma}} c_{R}=k^{\frac{1-\gamma}{\gamma}} c & \text { otherwise }
\end{array}
$$

Substituting the FOC into the budget constraint gives:

$$
c=\frac{\sum_{s=t}^{R} y_{s}+\sum_{s=R+1}^{T} B_{s}+A_{t}}{\left[R-t+1+k^{\frac{1-\gamma}{\gamma}}(T-R)\right]}
$$

The value function is the sum of flows of future utility when consumption is chosen at its optimal level:

$$
V_{t}\left(R, A_{t}\right)=\left(\sum_{s=t}^{R} y_{s}+\sum_{s=R+1}^{T} B_{s}+A_{t}\right)^{1-\gamma} \frac{\left(R-t+1+k^{\frac{1-\gamma}{\gamma}}(T-R)\right)^{\gamma}}{(1-\gamma)}
$$

For individuals deciding to postpone retirement optimally to $\bar{R}>R$ it must hold that:

$$
V_{t}\left(\bar{R}, A_{t}\right)>V_{t}\left(R, A_{t}\right)
$$

where

$$
V_{t}\left(\bar{R}, A_{t}\right)=\left(\sum_{s=t}^{\bar{R}} y_{s}+\sum_{s=\bar{R}+1}^{T} \bar{B}_{s}+A_{t}\right)^{1-\gamma} \frac{\left(\bar{R}-t+1+k^{\frac{1-\gamma}{\gamma}}(T-\bar{R})\right)^{\gamma}}{(1-\gamma)}
$$

with $\bar{B}>B$. Takings logs of (3) follows that for individuals deciding to postpone retirement the following inequality must hold:

\footnotetext{
${ }^{7}$ The general case with $r \neq 0$ provides the same testable implication of the simplified version and it is described in the Appendix.
} 


$$
\log \left(H_{\bar{R}}\right)-\log \left(H_{R}\right)>\frac{\gamma}{1-\gamma} \log \left[\frac{R-t+1+k^{\frac{1-\gamma}{\gamma}}(T-R)}{\bar{R}-t+1+k^{\frac{1-\gamma}{\gamma}}(T-\bar{R})}\right]
$$

where $H_{\bar{R}}$ and $H_{R}$ are the amount of resources under postponed retirement and early retirement, respectively.

$$
H_{\bar{R}}=\sum_{s=t}^{\bar{R}} y_{s}+\sum_{s=\bar{R}+1}^{T} \bar{B}_{s}+A_{t}
$$

and

$$
H_{R}=\sum_{s=t}^{R} y_{s}+\sum_{s=R+1}^{T} B_{s}+A_{t}
$$

We now want to introduce the possibility of taking care of the old parents when the individual is entitled to claim retirement, which is after age $R$. Suppose that the parents are alive until age $R_{3}$, which is higher than the early possible retirement age $(R)$ and the maximum retirement age allowed $\left(R_{2}\right)$. If the care of parents is bought in the market and the agent continues working up to $R_{2}$, we have the following inter-temporal utility function:

$$
\max _{c_{t}} U\left(c_{t}, c_{t+1}, \ldots, c_{T}\right)=\max _{c_{s}} \sum_{s=t}^{R_{3}} \frac{\left(c_{s}\right)^{1-\gamma}}{(1+\rho)^{s-t}(1-\gamma)}+\sum_{s=R_{3}+1}^{T} \frac{\left(k c_{s}\right)^{1-\gamma}}{(1+\rho)^{s-t}(1-\gamma)}
$$

subject to the following inter-temporal budget constraint

$$
\sum_{s=t}^{T} \frac{c_{s}}{(1+r)^{s-t}}=A_{t}+\sum_{s=t}^{R_{2}} \frac{y_{s}}{(1+r)^{s-t}}+\sum_{s=R_{2}+1}^{T} \frac{\bar{B}_{s}}{(1+r)^{s-t}}-\sum_{s=R+1}^{R_{2}} \frac{y_{s}^{c}}{(1+r)^{s-t}}
$$

Individuals start enjoying leisure only after $R_{3}$, which corresponds to their parents' death and we assume that they optimally decide to postpone the possible early retirement age $R$ to $R_{2}<R_{3}$ by paying the market cost of long-term care $y^{c}=w^{c} h$, for the time interval $R_{2}-R$, where $w^{c}$ is the hourly salary for elderly care-givers with $y_{s}>y_{s}^{c}$. After some 
algebra it follows that a similar inequality to (5) must hold:

$$
\log \left(H_{\bar{R}}\right)-\log \left(H_{R}\right)>\frac{\gamma}{1-\gamma} \log \left[\frac{(R-t+1)+k^{\frac{1-\gamma}{\gamma}}(T-R)}{\left(R_{3}-t+1\right)+k^{\frac{1-\gamma}{\gamma}}\left(T-R_{3}\right)}\right]
$$

where

$$
H_{\bar{R}}=\sum_{s=t}^{R_{2}} y_{s}+\sum_{s=R_{2}+1}^{T} \bar{B}_{s}+A_{t}-\sum_{s=R+1}^{R_{2}} y_{s}^{c}
$$

and

$$
H_{R}=\sum_{s=t}^{R} y_{s}+\sum_{s=R+1}^{T} B_{s}+A_{t}
$$

The testable implication is derived by taking the first derivative of equation (8) with respect to the market cost of long-term care, $y^{c}$. The main intuition is that a reduction in the market cost of long term care has a positive impact on the retirement age, as follows:

$$
\frac{\partial \log \left(H_{\bar{R}}\right)-\log \left(H_{R}\right)}{\partial y^{c}}=-\frac{1}{\left(\sum_{s=t}^{R_{2}} y_{s}+\sum_{s=R_{2}+1}^{T} \bar{B}_{s}+A_{t}-\sum_{s=R+1}^{R_{2}} y_{s}^{c}\right)}<0
$$

\section{Empirical strategy}

The empirical strategy which was adopted in order to estimate the determinants of retirement age follows a reduced-form approach, implemented, among others, by Brugiavini and Peracchi (2003, 2004), Chan and Stevens (2002, 2004), and Coile and Gruber (2000). Our basic estimating equation can be expressed as:

$$
y_{i j t}=\beta I_{j t}+\alpha\left(\log \left(\hat{H}_{\bar{R}}\right)-\log \left(\hat{H}_{R}\right)\right)_{i j t}+\mathbf{x}_{\mathbf{i j t}}{ }^{\prime} \gamma+D_{j}+\epsilon_{i j t}
$$

where the dependent variable represents the retirement age for individual $i$ residing in region $j$ at time $t$; more specifically, $y_{i j t}$ is the expected retirement age for those still 
working and the actual retirement age for those retiring during the sample period. $\mathbf{x}_{\mathbf{i j t}}$ represents a vector of individual characteristics: gender, three dummy variables relating to education (corresponding to compulsory education, high school and higher educationthe excluded category corresponds to no education), age, age squared, marital status, a dummy variable for having an employed partner, real and financial assets ${ }^{8}$, occupation (an indicator for white collar employment or a managerial position - the excluded category corresponds to blue collar employment ${ }^{9}$ ), dummy variables for the size of the town of residence, a dummy for retiring during the time of the study, and an indicator controlling for the respondent's eligibility for a seniority pension ${ }^{10}$. The respondent's health status is certainly another crucial determinant of retirement decision; unfortunately, the survey provides this information for only two waves (2006 and 2008) and therefore the number of observations is too low to include this regressor.

During the period of our analysis (2000-2008), Parliament approved a law which affected retirement decisions (Law n. 243, 23/08/2004) ${ }^{11}$. The law introduced two main changes which were relevant to retirement decisions: a fiscal incentive to foster the delay of early retirement and an increase in the minimum requirement for claiming a seniority pension. The first measure gave private employees who were eligible for a seniority pension the option of claiming exemption from pension contributions if they decided to continue working. The saving on contributions (corresponding to $32.7 \%$ of the gross salary) was received in its entirety by the worker on a tax-exempt basis. This incentive scheme should have operated up to 2008 at least, but in 2007 the new government decided to abolish it. It has been estimated that around 80,000 employees took advantage of these fiscal incentives. The second measure rose the minimum age of eligibility for a seniority pension by three years from 57 to 60 for private employees. We control for the impact of these fiscal incentives introduced by the law by introducing a dummy variable which was set as equal to one for respondents who were working as private employees and who were eligible for retirement during the period 2004-2007. We control for the increase in the minimum age of eligibility for a seniority pension through the indicator of eligibility. The role of financial incentives in retirement decisions was controlled for by introducing our estimated measure of the OV of working up to age $\bar{R}$, as follows:

$$
O V(\bar{R})_{i j}=\left(\log \left(\hat{H}_{\bar{R}}\right)-\log \left(\hat{H}_{R}\right)\right)_{i j}
$$

The computation will be detailed in the next section and in the Appendix. In addition, $I m_{j t}$ represents the immigration rate at the regional level, and $D_{j}$ denote regional fixed

\footnotetext{
${ }^{8}$ Our measure of real assets represents all real assets excluding all payments for mortgages, whereas financial assets do not exclude liabilities.

${ }^{9}$ However, by excluding liabilities from financial wealth the results change very little.

${ }^{10}$ Table 3 reports the variation over time in the requirements for eligibility for a seniority pension.

${ }^{11}$ For a detailed description of the 2004 pension reform, see Fornero and Sestito (2005).
} 
effects.

One of the possible factors that may weaken an OLS approach in our strategy for the identification of the impact of immigration in equation (9) is the endogeneity of immigrants. Immigrants are not randomly allocated to regions, but decide to reside in areas which are characterised by positive (unobservable) demand shocks, and thus more favourable labour market conditions constitute a pull factor, resulting in a positive correlation between the immigration rate variable and these omitted factors. At the same time, these unobserved factors can also affect the retirement decisions of natives; for instance, a positive demand shock can make working conditions too stressful, especially for older people who are eligible for retirement. Such changes in older people's working conditions might induce them to withdraw earlier from the labour force, thus bringing about a negative correlation between these omitted factors and the dependent variable. As a consequence, the OLS estimate would be biased downwards. In addition, our measure of the immigration rate is affected by measurement errors, as it only accounts for legal immigrants who are residents, thus discarding both immigrants who are legally present in Italy because they have been granted resident permits but are not (yet) registered as residents and the illegal ones ${ }^{12}$. This type of measurement error introduces an additional downward bias in the OLS coefficient. In order to control for the endogeneity we adopt an IV strategy which is broadly used in the literature on immigration and labour market.

This strategy is known as the supply-push component and was devised by Card (2001) in his seminal paper on the impact of immigration on natives' labour market outcomes. The rationale behind the instrument rests on the exploitation of the local settlement of immigrants from a given source country in the past as an exogenous determinant of the current local country-specific distribution. The current country-specific flow of immigrants to the host country is then distributed according to the regional distribution in the past.

The validity of this strategy relies upon two main requirements: local distribution in the past must be unrelated to current local pull factors, as simply stated we can claim that local demand shocks ought not to remain constant over time, and even in the case that these local pull factors persist over time, our specification controls for regional fixed effects which should account for any local constant factors. In addition, past and current local distributions have to be correlated, and this requirement is strongly supported by the broad empirical evidence regarding the tendency of newly-arrived immigrants to cluster in areas which are highly populated by immigrants from the same country in order to take advantage of the pre-established networks. The empirical findings suggest that this phenomenon is shared by many countries, as Cutler et al. (2008) provide substantive evidence for the US, whereas Aslund (2005) and Damm (2009) provide two examples for Sweden. However, our instrument controls for the endogeneity of the immigrants' location, but it does not control for measurement errors, which will also affect the instrument, as

\footnotetext{
${ }^{12}$ According to estimates based on ISMU (Iniziative e Studi sulla Multietnicità) data and provided by Blangiardo and Cesareo (2009), legal non-resident immigrants represent $13 \%$ of resident immigrants, whereas illegal immigrants represent $10 \%$ of resident immigrants.
} 
it only uses legal resident immigrants. As a result, also the final IV estimate is likely to be an underestimation of the true impact of immigration.

The instrument for the term representing the immigration rate in region $j$ at time $t$, $I m_{j t}$ is computed according to the following formula:

$$
I V_{j t}=\frac{\Sigma_{c} \lambda_{c j t_{0}} I m_{c t}}{\operatorname{Pop}_{j t}}
$$

where

$$
\lambda_{c j t_{0}}=\frac{I m_{c j t_{0}}}{I m_{c t_{0}}}
$$

represents the ratio of immigrants to Italy from country $c$ residing in region $j$ at time $t=t_{0}$. Our selected past distribution is relevant to the year $t_{0}=1991$ and represents the past distribution as computed from the 1991 Census data ${ }^{13}$. $I m_{c t}$ is the stock of immigrants in Italy from country $c$ at time $t$, and $P o p_{j t}$ is the total resident population in region $j$ at time $t$, both taken from registry data.

\section{Data}

In order to investigate the relationship between retirement age and the role of immigrants providing household services, we rely on three different sources of data: the SHIW, registry data for the total resident and immigrant population and the 1991 Census data for computing the regional distribution of immigrants in the past, which is represented by the term $\lambda_{c j t_{0}}$ as in (12).

The main data source is the SHIW, which has been run since 1965 by the Bank of Italy on a large random representative sample of the Italian population, with the latest available wave being relevant to 2008. Until 1987, the sample was only cross-sectional, whereas since 1989 and up to the latest wave, the survey has introduced a sub-sample of panel households. Every two years, the survey gathers information on about 8,000 households corresponding to about 24,000 individuals and provides data about the income, wealth and socio-demographic characteristics of family members. Since 1993, a special section has been devoted to collecting information about the family background of the head of the household and the spouse. Detailed information is provided about non-co-resident living parents, their age, their highest attained educational level and their occupation at the time when they were the same age as the respondent. We make use of these pieces of information in order to model the role of long-term care in the decision to retire and

\footnotetext{
${ }^{13}$ In Section 5, we describe in greater depth the data used for the implementation of the instrument.
} 
whether or not immigration has a different impact on people who are characterised by a higher burden in terms of family commitments.

As our aim is to model the determinants of retirement age we use the actual retirement age of those who retired during the period of analysis, whereas for those who had not yet retired we imputed the retirement age from the expected retirement age ${ }^{14}$. This information allows us to compute the financial incentives to retire corresponding to the optimal retirement age as stated by the individual and to compare these incentives with the ones computed at the counter-factual retirement age corresponding to immediate retirement ${ }^{15}$. Individuals were asked the following question: 'At what age do you expect to retire?' The information on the expected retirement age was available since the year 1989 for all waves up to 2008. However, this information alone is not sufficient to calculate the pension benefits for those still in employment, for whom we need to know the expected replacement rate as well as the expected retirement age. This survey elicited information about the expected replacement rate at the time of retirement by asking the following question: 'Think about when you will retire, and consider your public pension only (that is, exclude private pensions, if you have them). At the time of retirement, what fraction of your labour income will your public pension be?' This question was only available for the following years: 1989, 1991 and all years between 2000 and 2008. Therefore, our analysis is limited to the timespan 2000-2008.

The second source of data are registry data of the total resident and immigrant population at the regional level provided every year by ISTAT and disaggregated by country of origin. This source of data serves two purposes in carrying out our empirical analysis: first, by combining these data with the registry data regarding the total resident population, we compute the immigration rate by region, our main regressor of interest. Second, we use the number of resident immigrants by year and groups of countries of origin to compute the term $I m_{c t}$.

As we do not have information about the skill level of the immigrants and we need to isolate the low-skilled component of the immigrant labour supply, we define immigrants as those who were born outside of North America and the Western European countries, so as to exclude countries which unlikely provide low-skilled immigrants. For the construction of the instrument, we disaggregate the immigrant population according to groups of countries of origin which are more likely to constitute an enclave. Immigrants decide, once in the host country, to settle close to other immigrants who have similar cultures and traditions. According to this criterion, we categorise immigrants into the following five macro-groups of countries: Asia; Africa; South America; Eastern Europe; and others.

\footnotetext{
${ }^{14}$ The expected retirement age turns out to be a good proxy for the actual retirement age; the correlation coefficient between the two is equal to 0.715 , the mean value of the difference between expected retirement age and actual one is .623 , whereas the median value is equal to -1 .

${ }^{15}$ For those who retired during the timespan of the analysis we considered the immediate retirement corresponding to their actual retirement, whereas the postponed retirement corresponds to retire one year later.
} 
We use the 1991 Census as the third source of data in order to compute the regional distribution of immigrants in 1991 and to implement our instrument. Table 4 reports the distribution of immigrants by region and over time; the immigration rate varies by region and time, and there are no outliers potentially affecting the estimates.

Given the broad empirical evidence that immigrants represent the largest share of workers employed in the long-term care sector (78\%; see Table 1 and Figure 3 ) and that $30 \%$ of immigrant workers are employed in low-skilled occupations, we assume that an increase in the inflow of immigrants, as measured by the immigration rate, could have a substantial impact on the size of the household services sector. At the same time, recent structural estimates regarding the impact of immigration on the Italian wage structure show that the immigration which occurred over the period 1995-2004 reduced the wages of low-skilled immigrants by $1 \%$ (Romiti, 2011). We thus consider the rise in the immigration rate to be a proxy for the reduction in the market cost of long-term care. The preferred empirical strategy with which to identify the impact of immigrants on retirement decisions through the reduction of the average market cost of household services would be to use the cost of these services instead of the immigration rate. However, unfortunately, we do not have access to data on wages in this sector, because the only administrative data available are provided by the INPS, but the domestic sector is excluded from the available archive.

Our final sample consists of natives (heads of household or their spouses) who were employed or who retired during the timespan of the analysis and who were aged between 45 and 70. After excluding all individuals who did not meet the selection criteria or who had missing information on the regressors included in the analysis, our final sample consists of a cross-section of 6074 observations, of which 2264 represented women and 3810 represented men. Our empirical strategy consists of running separated regressions on different sub-samples, defined first in terms of gender. From each gender-specific sample we then select those with (at least) one elderly parent, with (at least) one elderly and low-educated parent, and with (at least) one elderly and low-skilled parent, where skill is defined in terms of occupation. Tables 5 and 6 report the descriptive statistics of the variables included in the analysis for each sub-sample in order to check for the presence of any compositional effects: the male respondents is slightly older than the female respondents, and therefore for the former sub-sample, the percentage of those eligible for retirement is higher, as is the proportion of those who retire during the study. The expected retirement age is lower for women (60.82 vs. 62.04), who are better educated than men, as almost $16 \%$ of the female sample holds a college degree, compared to $11 \%$ of the men. The mean value of the regional immigration rate does not differ across different sub-samples, corresponding to $4 \%$ of the regional population.

We use life tables disaggregated by year, gender, age and geographic location (defined by five macro-regions and provided by ISTAT) in order to recover the expected length of life for each respondent $(T)$. 
In order to compute our pension incentives measure, we need first to reconstruct the counter-factual earnings and the pension benefits of each worker, the computation we adopt for the earnings projection is described in details in the Appendix. In the computation of $H_{\bar{R}}$ and $H_{R}$, both $\bar{B}$ and $B$ are assumed to be constant. All financial values are expressed in real terms, deflated using the CPI-based index with base $=2000$.

\section{Estimation results}

Our main aim is to provide evidence that individuals with higher family commitments experience a positive impact of immigration in terms of postponing their retirement and staying in the labour force for longer.

Within the household, women are those who, mainly due to cultural reasons, bear most of the burden of household chores and long-term care (Lamura et al., 2008). Therefore, our main focus is to explore whether and to what extent immigrants affect male and female potential caregivers in different ways, and the differential effects on women (and men) with different degrees of family responsibility. For this purpose, we compare the results obtained by running separated regressions on different sub-samples. First of all, we compare the results obtained for women and men and, for each gender, we select those who were involved to a greater extent in family care activities such as having older parents who did not live with them ${ }^{16}$. We focus on parents who were not co-residing with their children, as we believe that women having to take care of their non-co-resident parents bear a higher burden compared to those who share a house with their parents; for instance, the time spent in reaching their parents' house is added to the time spent caring for them. Moreover, there is also evidence that this is the case in the US (Ettner, 1996) ${ }^{17}$. Unfortunately, we cannot check our hypothesis that the impact of immigration is actually lower in the case of daughters living with elderly parents with respect to those with non-co-resident parents empirically because the number of observations for the former sub-sample is too low (53 observations).

We then replicate the regression on sub-samples of both men and women with at least one elderly parent who was also low-educated, where a low level of education corresponds to compulsory school at most. This criterion is motivated on the grounds that education has a positive causal impact on health status, and particularly on the risk of mortality (Deaton and Paxson, 2004; Lleras-Muney, 2005). Therefore, we expect that elderly parents with a lower level of educational attainment, as they are less healthy than similar individuals with a higher degree of human capital endowment, represent a bigger burden

\footnotetext{
${ }^{16}$ We classified parents as elderly if they were 75 or older.

${ }^{17}$ Ettner (1996) found a differential impact of care-giving responsibilities on the intensive margin of the labour supply according to the type of care-giving recipient. Only caring for non-co-resident parents had a significantly negative impact on the labour supply, as opposed to a non-significant impact in the case of the demand for care within the household.
} 
in terms of the care activities required. We also replicate this analysis with a sub-sample of those with at least one elderly parent who was employed as blue-collar or not employed. In doing so, we isolate those parents with (probably) fewer resources, who were therefore less able to self-finance their long-term care needs by paying the cost of care on the market or by moving to a residential home. When parents have accumulated more resources during their life, the role of children as potential caregivers for elderly parents is much lower than that of children with similar parents but with fewer accumulated resources.

Tables 7 and 9 report the results obtained separately for the sub-samples of women and men and of women and men with at least one elderly non-co-resident parent for the OLS and the IV specifications, respectively. The first and second columns compare the results obtained for women and men. The evidence is strongly in favour of a differential impact of immigration according to gender: only women are positively affected by immigration, as the coefficient is non-significant for men, whereas immigrants significantly help the sample of women to postpone their retirement. These results hold true under OLS and IV specifications. The magnitude of the impact for women is such that the increase in the immigration rate which occurred during the period of our analysis (which corresponds to about 4 percentage points) brings about an increase in the expected retirement age for women which is equal to five months. We argue that this benefit that women gain from immigration involves both housekeeping and caring activities. By focusing on the impact for those who were more heavily involved in long-term care activities, we restrict our analysis to the sub-sample of women (and men) with at least one elderly and non-coresident parent. For this sub-sample, the impact of the rise in immigration experienced over the period 2000-2008 is higher, corresponding to a seven-month delay in respondents' expected exit from the labour force. However, for men, no impact has been found. The bottom of Table 9 clearly shows that the adopted instrument does not suffer from any weakness: the first stage of the endogenous variable has an $\mathrm{F} \mathrm{statistic}{ }^{18}$ which is far above the standard critical value (16.38) considered to be a sign of potential weakness. This latter property is confirmed by all other subsequent specifications ${ }^{19}$.

Tables 8 and 10 report the results obtained by replicating the analysis for the subsample of women (and men) with at least one elderly parent who was also low-educated (first and second columns), whereas the third and fourth columns report the results for blue-collar or not employed elderly parents. These results, throughout the specifications, clearly confirm and further stress the previous results. Only women gain from immigration, and women whose elderly parents are also low-educated - which we assume to be a proxy for ill-health - gain more than women with at least one elderly parent. Even higher

\footnotetext{
${ }^{18}$ As the immigration variable is aggregated at the region-year level, we need to correct for the potential correlation between individuals belonging to the same group in terms of region and year, therefore the standard errors are clustered at year-region level. Accordingly, the reported F statistics are robust to non i.i.d. errors Moulton (1990).

${ }^{19}$ We cannot compare the results shown in the third and fourth columns to the case of respondents with two young parents due to limited data. We had only 114 observations corresponding to women with two young parents and 160 observations for men.
} 
is the benefit gained by those women whose elderly parents are unable to self-finance their long-term care due to a lack of resources. If the channel through which immigrants help workers to postpone their retirement is through helping them to perform care-giving activities, these results point strongly in the expected direction. The magnitude of the impact of immigration on the latter results suggests that, as a consequence of the rise in immigration which occurred over the period 2000-2008, women extended their working career by 10 months if they had at least one elderly parent in poor health. The group of women who gained most from immigration was that with an elderly, poor, non-co-resident parent; these women postponed their exit from the labour force by almost one year (11.2 months).

Overall, all our findings strongly support the conclusion that immigrants, by contributing to household production and particularly to long-term care, help women in the age range of 45-70 to stay in the labour force for longer by increasing the opportunity cost of early retirement.

With regard to the impact of financial incentives on retirement decisions, the predicted measure of the OV is found to be highly significant and to have the expected positive sign, regardless of the specification adopted, confirming the results found in previous studies that financial incentives do matter in driving retirement decisions (Belloni and Alessie, 2009, 2010; Brugiavini and Peracchi, 2003, 2004; Chan and Stevens, 2002, 2004; Gruber and Wise, 2004).

With regard to the other regressors, our results show that people who were either married or in a couple retired earlier; however, education does not seem to play a significant role in retirement decisions for women, apart from the sub-sample of women with a poor elderly parent. In all other cases, better-educated women seem to retire later, but the coefficient is never significant. On the other hand, for men, education does seem to have a significantly positive impact on retirement decisions.

The results for occupation suggest that those working as managers retire later than blue-collar workers, even though this result is not always significant.

The age coefficient has a strong non-linear effect, suggesting that the (expected) retirement age initially declines with age and begins to increase later on. In particular, the expected retirement age for women declines until the age of 49.7, when it starts increasing; a similar path is followed by the retirement age for men, with a minimum reached at the age 51.

Regarding the other financial variables included in the analysis, wealth does not seem to play any role in shaping retirement decisions for women, as the relevant coefficients (real or financial) are never significant. This result is very different for men, for whom being wealthier in terms of real wealth helps to postpone retirement, whereas having accumulated more financial wealth has the opposite effect. The difference in terms of the impact of wealth according to gender points to an interesting result, and the fact that wealth does not play a role for women can be easily explained by the lack of female financial literacy 
(Lusardi and Mitchell, 2008) which has been shown to exist also for Italian women and which explains their lack of retirement planning (Fornero and Monticone, 2011).

Overall, the results provide strong support for our testable implication: immigrants contribute substantially to household production, and particularly to long-term care, as they help women to postpone their retirement, whereas they do not have any impact on men, who usually contribute substantially less to household production.

In particular, immigrants seem to be helpful in terms of long-term care, as they give relatively more support to daughters with living non-co-resident elderly parents. This support is even greater in the case of poor or less healthy elderly parents who carry a heavier burden in terms of family responsibilities.

According to our results, if Italy was to experience an immigration rate equal to $12 \%$, starting from the current scenario in which immigrants represent $7.1 \%$ of the resident population (ISTAT, 2010), the average retirement age for women (with at least one elderly non-co-resident parent) would rise to 61.7 , from the current average value of 60.45 . Our results suggest that the heavier the burden of family commitments, the greater the benefit of immigration for women: the average retirement age for women with at least one poor, elderly, non-co-residing parent would rise to 62.2 from the current average of 60.39 .

\section{Conclusions}

This paper investigates the determinants of retirement decisions for Italian workers, enriching the standard approach of the relevant literature, which mainly looks at the role played by financial incentives, by examining the pivotal role of the need for long-term care. Italy stands out among other OECD countries as having an extremely high dependency ratio, and as a consequence the increasing life expectancy and the associated increased morbidity for older people represents an unexplored potential driving factor for retirement decisions for those who are more heavily involved in family care. We argue that women, and particularly those with greater family commitments such as older (and poor in terms of resources or health) non-co-resident parents, are most affected by the increasing burden of long-term care. At the same time, they also gain more than anyone else from a flourishing and cheaper household services market and the long-term care brought about by the massive inflow of low-skilled immigrants.

Our results confirm the testable implications derived from our theoretical model: a decrease in the market cost of long-term care helps to postpone the retirement age. By using the inflow of immigrants as a proxy for the reduction in the price of household services, we have shown that immigrants help those responsible for household production to postpone their retirement by increasing the opportunity cost of early retirement.

The different results found according to gender and different types of potential recipients of care within the female sub-sample further emphasise our hypothesis. The dramatic gender difference suggests that the role played by immigration holds only for those who 
are traditionally involved in household production: according to our estimates, overall, women gain from immigration, whereas the latter does not have any impact on men. As a consequence, we first conclude that immigrants are substitutes for household production activities. In addition, the contribution made by immigrants rests particularly on their support in the field of long-term care, given that, restricting the analysis to daughters with non-co-resident parents, those with elderly parents gain much more from immigration. The positive impact of immigration is even higher for daughters whose older parents are poor in terms of resources or health. 


\section{References}

Aslund, O. (2005). Now and forever? initial and subsequent location choices of immigrants. Regional Science and Urban Economics, 35(2):141-165.

Barone, G. and Mocetti, S. (2011). With a little help from abroad: The effect of low-skilled immigration on the female labour supply. Labour Economics, 18(5):664-675.

Belloni, M. and Alessie, R. (2009). The importance of financial incentives on retirement choices: New evidence for italy. Labour Economics, 16(5):578-588.

Belloni, M. and Alessie, R. (2010). Retirement choices in italy: what an option value model tells us. Cerp working papers, Center for Research on Pensions and Welfare Policies, Turin (Italy).

Blangiardo, G. and Cesareo, V. (2009). Indici di integrazione. Un'indagine emnpirica sulla realta' migratoria italiana. Franco Angeli Editore.

Boeri, T., Del Boca, D., and Pissarides, C., editors (2005). Women at Work: An Economic Perspective. Oxford University Press.

Bolin, K., Lindgren, B., and Lundborg, P. (2008). Your next of kin or your own career?: Caring and working among the 50+ of europe. Journal of Health Economics, 27(3):718738.

Borella, M. and Moscarola, F. C. (2010). Microsimulation of pension reforms: behavioural versus nonbehavioural approach. Journal of Pension Economics and Finance, $9(04): 583-607$.

Borjas, G. J. (2003). The labor demand curve is downward sloping: Reexamining the impact of immigration on the labor market. The Quarterly Journal of Economics, 118(4):1335-1374.

Borjas, G. J., Grogger, J., and Hanson, G. H. (2008). Imperfect substitution between immigrants and natives: A reappraisal. Nber working papers, National Bureau of Economic Research, Inc.

Bottazzi, R., Jappelli, T., and Padula, M. (2006). Retirement expectations, pension reforms, and their impact on private wealth accumulation. Journal of Public Economics, 90(12):2187-2212.

Brugiavini, A. (1999). Social security and retirement in italy. In Social Security and Retirement around the World, NBER Chapters. National Bureau of Economic Research, Inc. 
Brugiavini, A. and Padula, M. (2001). Too much for retirement? saving in italy. Research in Economics, 55(1):39-60.

Brugiavini, A. and Peracchi, F. (2003). Social security wealth and retirement decisions in italy. LABOUR, 17(SpecialIs):79-114.

Brugiavini, A. and Peracchi, F. (2004). Micro-modeling of retirement behavior in italy. In Social Security Programs and Retirement around the World: Micro-Estimation, NBER Chapters. National Bureau of Economic Research, Inc.

Card, D. (1990). The impact of the mariel boatlift on the miami labor market. Industrial and Labor Relations Review, 43(2):245-257.

Card, D. (2001). Immigrant inflows, native outflows, and the local labor market impacts of higher immigration. Journal of Labor Economics, 19(1):22-64.

Card, D. (2007). How immigration affects u.s. cities. Cream discussion paper series, Centre for Research and Analysis of Migration (CReAM), Department of Economics, University College London.

Carmichael, F. and Charles, S. (1998). The labour market costs of community care. Journal of Health Economics, 17(6):747 - 765.

Carmichael, F. and Charles, S. (2003). The opportunity costs of informal care: does gender matter? Journal of Health Economics, 22(5):781-803.

Chan, S. and Stevens, A. H. (2002). How does job loss affect the timing of retirement? Nber working papers, National Bureau of Economic Research, Inc.

Chan, S. and Stevens, A. H. (2004). Do changes in pension incentives affect retirement? a longitudinal study of subjective retirement expectations. Journal of Public Economics, 88(7-8):1307-1333.

Coile, C. and Gruber, J. (2000). Social security incentives for retirement. NBER Working Papers 7651.

Cortès, P. and Tessada, J. (2001). Low-skilled immigration and the labor supply of highly skilled women. American Economic Journal: Applied Economics, 3(3):88-123.

Crespo, L. (2006). Caring for parents and employment status of european mid-life women. Working Papers wp2006 0615, CEMFI.

Cutler, D. M., Glaeser, E. L., and Vigdor, J. L. (2008). When are ghettos bad? lessons from immigrant segregation in the united states. Journal of Urban Economics, 63(3):759-774. 
Damm, A. (2009). Determinants of recent immigrants' location choices: quasiexperimental evidence. Journal of Population Economics, 22(1):145-174.

D'Amuri, F., Ottaviano, G. I., and Peri, G. (2010). The labor market impact of immigration in western germany in the 1990s. European Economic Review, 54(4):550-570.

Deaton, A. S. and Paxson, C. (2004). Mortality, income, and income inequality over time in britain and the united states. In Perspectives on the Economics of Aging, NBER Chapters. National Bureau of Economic Research, Inc.

Dustmann, C., Fabbri, F., and Preston, I. (2005). The impact of immigration on the british labour market. Economic Journal, 115(507):F324-F341.

Ettner, S. L. (1996). The opportunity costs of elder care. The Journal of Human Resources, 31(1):189.

Farrè, L., Gonzàlez, L., and Ortega, F. (2011). Immigration, family responsibilities and the labor supply of skilled native women. The B.E. Journal of Economic Analysis and Policy, 11(1):1-46.

Fornero, E. and Monticone, C. (2011). Financial literacy and pension plan participation in italy. Cerp working papers, Center for Research on Pensions and Welfare Policies, Turin (Italy).

Fornero, E. and Sestito, P., editors (2005). Pension Systems: Beyond Mandatory Retirement. Edward Elgar Publishing.

Gavosto, A., Venturini, A., and Villosio, C. (1999). Do immigrants compete with natives? LABOUR, 13(3):603-621.

Gruber, J. and Wise, D. A. (2004). Social Security Programs and Retirement around the World: Micro-Estimation. NBER Books. National Bureau of Economic Research, Inc.

Kolodinsky, J. and Shirey, L. (2000). The impact of living with an elder parent on adult daughter's labor supply and hours of work. Journal of Family and Economic Issues, $21: 149-175$.

Lamura, G., Mnich, E., Nolan, M., Wojszel, B., Krevers, B., Mestheneos, L., Döhner, H., and on behalf of the EUROFAMCARE Group (2008). Family carers' experiences using support services in europe: Empirical evidence from the eurofamcare study. The Gerontologist, 48(6):752-771.

Lleras-Muney, A. (2005). The relationship between education and adult mortality in the united states. Review of Economic Studies, 72(1):189-221. 
Lumsdaine, R. L., Stock, J. H., and Wise, D. A. (1992). Three models of retirement: Computational complexity versus predictive validity. In Topics in the Economics of Aging, NBER Chapters, pages 21-60. National Bureau of Economic Research, Inc.

Lusardi, A. and Mitchell, O. S. (2008). Planning and financial literacy: How do women fare? American Economic Review, 98(2):413-417.

Marenzi, A. and Pagani, L. (2008). The labor market participation of sandwich generation italian women. Journal of Family and Economic Issues, 29(3):427-444.

Moulton, B. R. (1990). An Illustration of a Pitfall in Estimating the Effects of Aggregate Variables on Micro Units. The Review of Economics and Statistics, 72(2):334-338.

Ottaviano, G. I. and Peri, G. (2008). Immigration and national wages: Clarifying the theory and the empirics. Nber working papers, National Bureau of Economic Research, Inc.

Ottaviano, G. I. and Peri, G. (2011). Rethinking the effects of immigration on wages. Journal of the European Economic Association, forthcoming.

Peri, G. (2007). Immigrants' complementarities and native wages: Evidence from california. Nber working papers, National Bureau of Economic Research, Inc.

Romiti, A. (2011). Immigrants-natives complementarities in production: evidence from italy. CeRP Working Papers 105, Center for Research on Pensions and Welfare Policies, Turin (Italy).

Samwick, A. A. (1998). New evidence on pensions, social security, and the timing of retirement. Journal of Public Economics, 70(2):207-236.

Stock, J. H. and Wise, D. A. (1990). Pensions, the Option Value of Work, and Retirement. Econometrica, 58(5):1151-1180.

Wolf, D. A. and Soldo, B. J. (1994). Married women's allocation of time to employment and care of elderly parents. The Journal of Human Resources, 29(4):1259-1276. 


\section{Appendix}

\section{A1. Theoretical appendix}

Individuals are assumed to face the following inter-temporal maximization problem

$$
\max _{c_{t}} U\left(c_{t}, c_{t+1}, \ldots, c_{T}\right)=\max _{c_{s}} \sum_{s=t}^{R} \frac{u\left(c_{s}\right)}{(1+\rho)^{s-t}}+\sum_{s=R+1}^{T} \frac{u\left(k c_{s}\right)}{(1+\rho)^{s-t}}
$$

where the utility function is represented by a CRRA

$$
\max _{c_{t}} U\left(c_{t}, c_{t+1}, \ldots, c_{T}\right)=\max _{c_{t}, c_{t+1} . . c_{T c}} \sum_{s=t}^{R} \frac{\left(c_{s}\right)^{1-\gamma}}{(1+\rho)^{s-t}(1-\gamma)}+\sum_{s=R+1}^{T} \frac{\left(k c_{s}\right)^{1-\gamma}}{(1+\rho)^{s-t}(1-\gamma)}
$$

subject to the following budget constraints

$$
\begin{array}{ll}
A_{t+1}=(1+r)\left(A_{t}+y_{t}-c_{t}\right) & \text { if } t \in[t, R] \\
A_{t+1}=(1+r)\left(A_{t}-c_{t}+B_{t}\right) & \text { if } t \in[R+1, T]
\end{array}
$$

where $A_{t}$ is an asset given at the beginning of the observed period, $B_{t}$ is pension benefit, $R$ is retirement date, $T$ is the expected length of life, $k>1$ accounts for leisure after retirement. We assume that workers can't leave either debts, nor bequest, i.e. $A_{T+1}=0$. The inter-temporal budget constraints is then equal to

$$
\sum_{s=t}^{T} \frac{c_{s}}{(1+r)^{s-t}}=A_{t}+\sum_{s=t}^{R} \frac{y_{s}}{(1+r)^{s-t}}+\sum_{s=R+1}^{T} \frac{B_{s}}{(1+r)^{s-t}}
$$

and the first order conditions yield

$$
\begin{array}{ll}
c_{t}=\left[\lambda\left(\frac{1+\rho}{1+r}\right)^{t}\right]^{-\frac{1}{\gamma}} & \text { if } t \in[t, R] \\
c_{t}=\left[\lambda\left(\frac{1+\rho}{1+r}\right)^{t}\right]^{-\frac{1}{\gamma}} k^{\frac{1-\gamma}{\gamma}} & \text { if } t \in[R+1, T]
\end{array}
$$

If $\rho=r$, it follows that 


$$
\begin{array}{ll}
c_{t}=c & \text { if } t \in[t, R] \\
c_{t}=k^{\frac{1-\gamma}{\gamma}} c & \text { if } t \in[R+1, T]
\end{array}
$$

Plugging the optimal path of $c$ in (15) follows the optimal consumption

$$
c=\frac{\sum_{s=t}^{R} \beta^{s-t} y_{s}+\sum_{s=R+1}^{T} \beta^{s-t} B_{s}+A_{t}}{\left[\frac{\beta^{t}-\beta^{R+1}}{\beta^{t}(1-\beta)}+\frac{k^{\frac{1-\gamma}{\gamma}}\left(\beta^{R+1}-\beta^{T+1}\right)}{\beta^{t}(1-\beta)}\right]}
$$

After some algebra the value function is equal to

$$
V_{t}\left(R, A_{t}\right)=\left(\frac{H_{R}}{\left[\frac{\beta^{t}-\beta^{R+1}}{\beta^{t}(1-\beta)}+\frac{k^{\frac{1-\gamma}{\gamma}}\left(\beta^{R+1}-\beta^{T+1}\right)}{\beta^{t}(1-\beta)}\right]}\right)^{1-\gamma}\left[\frac{\left(\beta^{t}-\beta^{R+1}\right)+k^{\frac{1-\gamma}{\gamma}}\left(\beta^{R+1}-\beta^{T+1}\right)}{(1-\gamma) \beta^{t}(1-\beta)}\right]
$$

where

$$
H_{R}=\sum_{s=t}^{R} y_{s}+\sum_{s=R+1}^{T} B_{s}+A_{t}
$$

Individuals optimally choosing to postpone retirement to $\bar{R}$ face the following maximization problem

$$
\max _{c_{t}} U\left(c_{t}, c_{t+1}, \ldots, c_{T}\right)=\max _{c_{t}, c_{t+1} . . c_{T c}} \sum_{s=t}^{\bar{R}} \frac{\left(c_{s}\right)^{1-\gamma}}{(1+\rho)^{s-t}(1-\gamma)}+\sum_{s=\bar{R}+1}^{T} \frac{\left(k c_{s}\right)^{1-\gamma}}{(1+\rho)^{s-t}(1-\gamma)}
$$

subject to the following inter-temporal budget constraint

$$
\sum_{s=t}^{T} \frac{c_{s}}{(1+r)^{s-t}}=A_{t}+\sum_{s=t}^{\bar{R}} \frac{y_{s}}{(1+r)^{s-t}}+\sum_{s=\bar{R}+1}^{T} \frac{\bar{B}_{s}}{(1+r)^{s-t}}
$$


The first order conditions yield

$$
\begin{array}{ll}
c_{t}=\left[\lambda\left(\frac{1+\rho}{1+r}\right)^{t}\right]^{-\frac{1}{\gamma}} & \text { if } t \in[t, \bar{R}] \\
c_{t}=\left[\lambda\left(\frac{1+\rho}{1+r}\right)^{t}\right]^{-\frac{1}{\gamma}} k^{\frac{1-\gamma}{\gamma}} & \text { if } t \in[\bar{R}+1, T]
\end{array}
$$

If $\rho=r$, it follows that

$$
\begin{array}{ll}
c_{t}=c & \text { if } t \in[t, \bar{R}] \\
c_{t}=k^{\frac{1-\gamma}{\gamma}} c & \text { if } t \in[\bar{R}+1, T]
\end{array}
$$

Plugging the optimal path of $c$ in (16) it follows the optimal consumption

$$
c=\frac{\sum_{s=t}^{\bar{R}} \beta^{s-t} y_{s}+\sum_{s=\bar{R}+1}^{T} \beta^{s-t} \bar{B}_{s}+A_{t}}{\left[\frac{\beta^{t}-\beta^{\bar{R}+1}}{\beta^{t}(1-\beta)}+\frac{k^{\frac{1-\gamma}{\gamma}}\left(\beta^{\bar{R}+1}-\beta^{T+1}\right)}{\beta^{t}(1-\beta)}\right]}
$$

The value function is equal to

$$
V_{t}\left(\bar{R}, A_{t}\right)=\left(\frac{H_{\bar{R}}}{\frac{\beta^{t}-\beta^{\bar{R}+1}}{\beta^{t}(1-\beta)}+\frac{k^{\frac{1-\gamma}{\gamma}}\left(\beta^{\bar{R}+1}-\beta^{T+1}\right)}{\beta^{t}(1-\beta)}}\right)^{1-\gamma}\left[\frac{\left(\beta^{t}-\beta^{\bar{R}+1}\right)+k^{\frac{1-\gamma}{\gamma}}\left(\beta^{\bar{R}+1}-\beta^{T+1}\right)}{(1-\gamma) \beta^{t}(1-\beta)}\right]
$$

where

$$
H_{\bar{R}}=\sum_{s=t}^{\bar{R}} y_{s}+\sum_{s=\bar{R}+1}^{T} \bar{B}_{s}+A_{t}
$$

Follows that workers postpone retirement if

$$
V_{t}(\bar{R})>V_{t}(R)
$$




$$
\frac{H_{P R}}{H_{R}}>\left[\frac{\beta^{t}-\beta^{R+1}+k^{\frac{1-\gamma}{\gamma}}\left(\beta^{R+1}-\beta^{T+1}\right)}{\beta^{t}-\beta^{\bar{R}+1}+k^{\frac{1-\gamma}{\gamma}}\left(\beta^{\bar{R}+1}-\beta^{T+1}\right)}\right]^{\frac{\gamma}{1-\gamma}}
$$

Taking logs of (17), it follows that workers postpone retirement if

$$
\log H_{\bar{R}}-\log H_{R}>\frac{\gamma}{1-\gamma} \log \left[\frac{\beta^{t}-\beta^{R+1}+k^{\frac{1-\gamma}{\gamma}}\left(\beta^{R+1}-\beta^{T+1}\right)}{\beta^{t}-\beta^{\bar{R}+1}+k^{\frac{1-\gamma}{\gamma}}\left(\beta^{\bar{R}+1}-\beta^{T+1}\right)}\right]
$$

Introducing the market cost of long-term care, individuals with elderly living parents face the following modified version of the maximization problem as in (14)

$$
\max _{c_{t}} U\left(c_{t}, c_{t+1}, \ldots, c_{T}\right)=\max _{c_{t}, c_{t+1} . . . c_{T c}} \sum_{s=t}^{R_{3}} \frac{\left(c_{s}\right)^{1-\gamma}}{(1+\rho)^{s-t}(1-\gamma)}+\sum_{s=R_{3}+1}^{T} \frac{\left(k c_{s}\right)^{1-\gamma}}{(1+\rho)^{s-t}(1-\gamma)}
$$

subject to the following inter-temporal budget constraint

$$
\sum_{s=t}^{T} \frac{c_{s}}{(1+r)^{s-t}}=A_{t}+\sum_{s=t}^{R_{2}} \frac{y_{s}}{(1+r)^{s-t}}+\sum_{s=R_{2}+1}^{T} \frac{\bar{B}_{s}}{(1+r)^{s-t}}-\sum_{s=R+1}^{R_{2}} \frac{y_{s}^{c}}{(1+r)^{s-t}}
$$

where $R_{3}$ is the dead of elderly parents. The first order conditions yield

$$
\begin{array}{ll}
c_{t}=\left[\lambda\left(\frac{1+\rho}{1+r}\right)^{t}\right]^{-\frac{1}{\gamma}} & \text { if } t \in\left[t, R_{3}\right] \\
c_{t}=\left[\lambda\left(\frac{1+\rho}{1+r}\right)^{t}\right]^{-\frac{1}{\gamma}} k^{\frac{1-\gamma}{\gamma}} & \text { if } t \in\left[R_{3}+1, T\right]
\end{array}
$$

If $\rho=r$, it follows that

$$
\begin{array}{ll}
c_{t}=c & \text { if } t \in\left[t, R_{3}\right] \\
c_{t}=k^{\frac{1-\gamma}{\gamma}} c & \text { if } t \in\left[R_{3}+1, T\right]
\end{array}
$$

Plugging the optimal path of $c$ in (19) it follows the optimal consumption 


$$
c=\frac{\sum_{s=t}^{R_{2}} \beta^{s-t} y_{s}+\sum_{s=R_{2}+1}^{T} \beta^{s-t} \bar{B}_{s}+A_{t}-\sum_{s=R+1}^{R_{2}} \beta^{s-t} y_{s}^{c}}{\left[\frac{\beta^{t}-\beta^{R_{3}+1}}{\beta^{t}(1-\beta)}+\frac{k^{\frac{1-\gamma}{\gamma}}\left(\beta^{R_{3}+1}-\beta^{T+1}\right)}{\beta^{t}(1-\beta)}\right]}
$$

The value function is equal to

$$
V_{t}\left(\bar{R}, A_{t}\right)=\left(\frac{H_{\bar{R}}^{*}}{\frac{\beta^{t}-\beta^{R_{3}+1}}{\beta^{t}(1-\beta)}+\frac{k^{\frac{1-\gamma}{\gamma}}\left(\beta^{R_{3}+1}-\beta^{T+1}\right)}{\beta^{t}(1-\beta)}}\right)^{1-\gamma}\left[\frac{\left(\beta^{t}-\beta^{R_{3}+1}\right)+k^{\frac{1-\gamma}{\gamma}}\left(\beta^{R_{3}+1}-\beta^{T+1}\right)}{(1-\gamma) \beta^{t}(1-\beta)}\right]
$$

where

$$
H_{\bar{R}}^{*}=\sum_{s=t}^{R_{2}} y_{s}+\sum_{s=R_{2}+1}^{T} \bar{B}_{s}+A_{t}-\sum_{s=R+1}^{R_{2}} y_{s}^{c}
$$

It follows that workers postpone retirement if

$$
V_{t}\left(\bar{R}, A_{t}\right)>V_{t}\left(R, A_{t}\right)
$$

which is equivalent to

$$
\frac{H_{\bar{R}}^{*}}{H_{R}}>\left[\frac{\beta^{t}-\beta^{R+1}+k^{\frac{1-\gamma}{\gamma}}\left(\beta^{R+1}-\beta^{T+1}\right)}{\beta^{t}-\beta^{R_{3}+1}+k^{\frac{1-\gamma}{\gamma}}\left(\beta^{R_{3}+1}-\beta^{T+1}\right)}\right]^{\frac{\gamma}{1-\gamma}}
$$

Taking logs, it follows that workers postpone retirement if

$$
\log \left(H_{\bar{R}}^{*}\right)-\log \left(H_{R}\right)>\frac{\gamma}{1-\gamma} \log \left[\frac{\beta^{t}-\beta^{R+1}+k^{\frac{1-\gamma}{\gamma}}\left(\beta^{R+1}-\beta^{T+1}\right)}{\beta^{t}-\beta^{R_{3}+1}+k^{\frac{1-\gamma}{\gamma}}\left(\beta^{R_{3}+1}-\beta^{T+1}\right)}\right]
$$

From (20) it follows that, increasing the market cost of formal long-term care has a negative impact on postponing retirement age, since 


$$
\frac{\partial \log \left(H_{\bar{R}}^{*}\right)-\log \left(H_{R}\right)}{\partial y^{c}}=-\frac{1}{\left(\sum_{s=t}^{R_{2}} y_{s}+\sum_{s=R_{2}+1}^{T} \bar{B}_{s}+A_{R}-\sum_{s=R+1}^{R_{2}} y_{s}^{c}\right)}<0
$$

under our assumption that $y_{s}>y_{s}^{c}$.

\section{A2. Earnings and pension benefits projection}

Different strategies are adopted for different types of worker. For workers who had not retired, we need to recover the counter-factual earnings corresponding to the year before their expected retirement in order to compute the relevant expected pension benefits, $\bar{B}$. Therefore, individual earnings are projected forward up to the year prior to their expected retirement, applying the constant growth rate of real earnings per capita corresponding to the last year in which they featured in the sample. We compute the per capita (real) earning growth rate by using the growth rate of earning at national level ${ }^{20}$. In order to compute the pension benefit in cases of immediate retirement, we need to recover the expected replacement rate corresponding to the last year in which the individuals featured in the sample. However, the data provided only the expected replacement rate for the year when the respondent expected to retire. We therefore predict the expected replacement rate using the following regression:

$$
y_{i t}=\beta z_{i t}+\mathbf{x}_{\mathbf{i t}}^{\prime} \gamma+D_{t}+\epsilon_{i t}
$$

where $y_{i t}$ is the expected replacement rate provided by the survey and $z_{i t}$ represents the years of contributions expected to be paid before retirement. In order to compute the latter variable, we use the information provided by the survey regarding the number of years of contributions paid by workers at the time of the interview, and we assume that each worker would pay contributions for the remaining years up to their expected retirement age. $\mathbf{x}_{\mathbf{i t}}$ is a vector of individual characteristics including gender, education, type of occupation and civil status, $D_{t}$ is a time dummy and $\epsilon_{i t}$ is the standard zeromean error term. We then use the coefficients estimated in equation (21) to predict the expected replacement rate corresponding to immediate retirement. This predicted value is applied to the earnings corresponding to the penultimate year in order to recover the benefits in cases of immediate retirement $(B)$. For workers who retired during the

\footnotetext{
${ }^{20}$ For an alternative earnings projection strategy see Borella and Moscarola (2010) who model individual earnings profiles by using a regression model, which controls for age, cohort, regional and time dummies, plus and additional individual random effect, and with the error term following an AR(1) process.
} 
survey, we observe their actual pension benefits $(B)$. For these respondents, we assume that a postponed retirement would correspond to retirement one year after their effective retirement, and we need to recover the counter-factual earnings relevant to the year in which they effectively retired in order to compute the pension benefit in the case of postponed retirement, $\bar{B}$. Once we have the counter-factual replacement rate, we project the respondents' last observed earnings using the relevant annual growth rate of per capita earnings to the year corresponding to their actual retirement and we multiply the latter by the predicted replacement rate. 
Table 1: Domestic workers: distribution by immigration status.

\begin{tabular}{lcc}
\hline Year & Immigrants & Natives \\
\hline 2000 & 51.64 & 48.35 \\
2001 & 52.87 & 47.13 \\
2002 & 76.26 & 23.74 \\
2003 & 78.06 & 21.93 \\
2004 & 73.85 & 26.15 \\
2005 & 68.40 & 31.60 \\
2006 & 71.54 & 28.46 \\
2007 & 79.63 & 20.37 \\
2008 & 78.13 & 21.87 \\
\hline
\end{tabular}

Source: INPS (2000-2008)

Table 2: Average (expected) retirement age.

\begin{tabular}{lccccc}
\hline & $\mathbf{2 0 0 0}$ & $\mathbf{2 0 0 2}$ & $\mathbf{2 0 0 4}$ & $\mathbf{2 0 0 6}$ & $\mathbf{2 0 0 8}$ \\
\hline Women & & & & & \\
\hline & 59.74 & 60.44 & 60.71 & 60.71 & 61.30 \\
\hline Men & & & & & \\
\hline & 61.03 & 61.42 & 61.83 & 61.85 & 62.54 \\
\hline
\end{tabular}

Sample: respondents from SHIW (2000-2008), age range 45-70.

Table 3: Eligibility requirement for seniority pensions.

\begin{tabular}{ccccccc}
\hline & \multicolumn{3}{c}{ Public } & \multicolumn{3}{c}{ Private } \\
\cline { 2 - 7 } Year & Age & Seniority & Only Sen & Age & Seniority & Only Sen \\
\hline 2000 & 54 & 35 & 37 & 55 & 35 & 37 \\
2002 & 55 & 35 & 37 & 57 & 35 & 37 \\
2004 & 57 & 35 & 38 & 57 & 35 & 38 \\
2006 & 57 & 35 & 39 & 57 & 35 & 39 \\
2008 & 57 & 35 & 40 & 60 & 35 & 40 \\
\hline
\end{tabular}


Table 4: Distribution of immigrants by regions.

\begin{tabular}{lccc}
\hline & Total & 2000 & 2008 \\
\hline Piemonte & 0.046 & 0.023 & 0.076 \\
Valle d'Aosta & 0.038 & 0.016 & 0.055 \\
Lombardia & 0.06 & 0.033 & 0.089 \\
Trentino & 0.047 & 0.024 & 0.069 \\
Veneto & 0.064 & 0.029 & 0.091 \\
Friuli & 0.05 & 0.024 & 0.074 \\
Liguria & 0.039 & 0.019 & 0.06 \\
Emilia Romagna & 0.062 & 0.03 & 0.094 \\
Toscana & 0.051 & 0.027 & 0.078 \\
Umbria & 0.062 & 0.031 & 0.09 \\
Marche & 0.047 & 0.026 & 0.08 \\
Lazio & 0.031 & 0.038 & 0.074 \\
Abruzzo & 0.015 & 0.016 & 0.05 \\
Molise & 0.013 & 0.006 & 0.022 \\
Campania & 0.011 & 0.008 & 0.022 \\
Puglia & 0.011 & 0.008 & 0.017 \\
Basilicata & 0.011 & 0.005 & 0.019 \\
Calabria & 0.016 & 0.009 & 0.028 \\
Sicilia & 0.014 & 0.012 & 0.021 \\
Sardegna & 0.01 & 0.006 & 0.015 \\
\hline
\end{tabular}

Source: registry data, 2000-2008. 
Table 5: Summary statistics

\begin{tabular}{|c|c|c|c|c|}
\hline & Women & Men & $\begin{array}{l}\text { Women with } \\
\text { old parent }\end{array}$ & $\begin{array}{l}\text { Men with } \\
\text { old parent }\end{array}$ \\
\hline Retir age & 60.82 & 62.04 & 60.45 & 61.47 \\
\hline OV & 0.141 & 0.149 & 0.132 & 0.156 \\
\hline Imrate & 0.0481 & 0.0392 & 0.0428 & 0.0416 \\
\hline Age & 51.91 & 53.26 & 50.94 & 51.91 \\
\hline Eligible & 0.0962 & 0.149 & 0.0651 & 0.105 \\
\hline Employed & 0.934 & 0.898 & 0.959 & 0.931 \\
\hline Retired & 0.0655 & 0.102 & 0.0410 & 0.0694 \\
\hline Labour earnings & 12232.3 & 15011.2 & 12818.1 & 17578.4 \\
\hline Married & 0.711 & 0.879 & 0.713 & 0.920 \\
\hline Single & 0.105 & 0.0613 & 0.0760 & 0.0280 \\
\hline Divorced & 0.118 & 0.0474 & 0.156 & 0.0463 \\
\hline Widowed & 0.0662 & 0.0122 & 0.0555 & 0.00561 \\
\hline Employed partner & 0.500 & 0.401 & 0.521 & 0.495 \\
\hline Financ wealth & 19469.5 & 15526.0 & 21402.9 & 21501.2 \\
\hline Real wealth & 201285.1 & 174095.1 & 225780.5 & 202326.2 \\
\hline White collar & 0.630 & 0.446 & 0.647 & 0.542 \\
\hline Manager & 0.0181 & 0.0567 & 0.0326 & 0.0855 \\
\hline Blue collar & 0.352 & 0.497 & 0.321 & 0.372 \\
\hline No edu & 0.00767 & 0.0155 & 0.00603 & 0.00491 \\
\hline Compuls school & 0.405 & 0.532 & 0.346 & 0.406 \\
\hline High school & 0.429 & 0.337 & 0.455 & 0.428 \\
\hline College or higher edu & 0.158 & 0.115 & 0.193 & 0.160 \\
\hline Town size $0-20000$ & 0.263 & 0.246 & 0.255 & 0.263 \\
\hline Town size $20000-40000$ & 0.181 & 0.184 & 0.229 & 0.183 \\
\hline Town size $40000-500000$ & 0.468 & 0.469 & 0.422 & 0.448 \\
\hline Town size $500000+$ & 0.0871 & 0.101 & 0.0941 & 0.107 \\
\hline North East & 0.263 & 0.214 & 0.294 & 0.265 \\
\hline North West & 0.243 & 0.180 & 0.240 & 0.188 \\
\hline Centre & 0.238 & 0.212 & 0.220 & 0.207 \\
\hline South & 0.171 & 0.274 & 0.165 & 0.220 \\
\hline Islands & 0.0850 & 0.119 & 0.0808 & 0.120 \\
\hline Obs & 2264 & 3810 & 829 & 1427 \\
\hline
\end{tabular}

Source: SHIW, 2000-2008. 
Table 6: Summary statistics

\begin{tabular}{|c|c|c|c|c|}
\hline & $\begin{array}{c}\text { Women with } \\
\text { old \& low } \\
\text { edu parent }\end{array}$ & $\begin{array}{l}\text { Men with } \\
\text { old \& low } \\
\text { edu parent }\end{array}$ & $\begin{array}{l}\text { Women with } \\
\text { old \& low } \\
\text { occ parent }\end{array}$ & $\begin{array}{l}\text { Men with } \\
\text { old \& low } \\
\text { occ parent }\end{array}$ \\
\hline Retir age & 60.15 & 61.60 & 60.39 & 61.26 \\
\hline $\mathrm{OV}$ & 0.131 & 0.160 & 0.131 & 0.152 \\
\hline Imrate & 0.0424 & 0.0405 & 0.0424 & 0.0414 \\
\hline Age & 50.72 & 51.72 & 51.11 & 52.06 \\
\hline Eligible & 0.0738 & 0.126 & 0.0627 & 0.109 \\
\hline Employed & 0.953 & 0.931 & 0.960 & 0.926 \\
\hline Retired & 0.0470 & 0.0693 & 0.0402 & 0.0744 \\
\hline Labor earnings & 12493.4 & 17234.8 & 12164.8 & 16883.0 \\
\hline Married & 0.644 & 0.900 & 0.738 & 0.926 \\
\hline Single & 0.0940 & 0.0216 & 0.0563 & 0.0269 \\
\hline Divorced & 0.201 & 0.0649 & 0.145 & 0.0430 \\
\hline Widowed & 0.0604 & 0.0130 & 0.0611 & 0.00448 \\
\hline Employed partner & 0.490 & 0.506 & 0.529 & 0.475 \\
\hline Financ wealth & 23952.9 & 28056.0 & 17518.2 & 19331.7 \\
\hline Real wealth & 257709.8 & 214408.9 & 212729.8 & 182214.5 \\
\hline White collar & 0.705 & 0.623 & 0.621 & 0.520 \\
\hline Manager & 0.0268 & 0.0866 & 0.0193 & 0.0673 \\
\hline Blue collar & 0.268 & 0.290 & 0.360 & 0.413 \\
\hline No edu & 0.0134 & 0.00433 & 0.00482 & 0.00538 \\
\hline Compuls school & 0.268 & 0.368 & 0.394 & 0.442 \\
\hline High school & 0.537 & 0.433 & 0.441 & 0.430 \\
\hline College or higher edu & 0.181 & 0.195 & 0.161 & 0.123 \\
\hline Town size 0-20000 & 0.248 & 0.255 & 0.272 & 0.270 \\
\hline Town size $20000-40000$ & 0.215 & 0.177 & 0.236 & 0.187 \\
\hline Town size $40000-500000$ & 0.430 & 0.476 & 0.412 & 0.439 \\
\hline Town size $500000+$ & 0.107 & 0.0909 & 0.0804 & 0.103 \\
\hline North East & 0.322 & 0.208 & 0.280 & 0.265 \\
\hline North West & 0.242 & 0.186 & 0.251 & 0.190 \\
\hline Centre & 0.255 & 0.229 & 0.201 & 0.205 \\
\hline South & 0.121 & 0.273 & 0.180 & 0.215 \\
\hline Islands & 0.0604 & 0.104 & 0.0884 & 0.124 \\
\hline Obs & 752 & 1309 & 622 & 1115 \\
\hline
\end{tabular}

Source: SHIW, 2000-2008. 
Table 7: OLS

\begin{tabular}{|c|c|c|c|c|}
\hline Dep var: Ret age & Women & Men & $\begin{array}{l}\text { Wom with } \\
\text { old parent }\end{array}$ & $\begin{array}{l}\text { Men with } \\
\text { old parent }\end{array}$ \\
\hline Imrate & $\begin{array}{c}8.640^{* *} \\
(3.822)\end{array}$ & $\begin{array}{c}6.157 \\
(4.958)\end{array}$ & $\begin{array}{c}13.237^{*} \\
(7.221)\end{array}$ & $\begin{array}{c}-0.298 \\
(8.496)\end{array}$ \\
\hline $\mathrm{OV}$ & $\begin{array}{c}5.299^{* * *} \\
(0.544)\end{array}$ & $\begin{array}{c}7.896^{* * *} \\
(0.732)\end{array}$ & $\begin{array}{c}4.900^{* * *} \\
(1.034)\end{array}$ & $\begin{array}{c}9.361^{* * *} \\
(1.462)\end{array}$ \\
\hline Age & $\begin{array}{c}-3.183^{* * *} \\
(0.239)\end{array}$ & $\begin{array}{c}-3.345^{* * *} \\
(0.165)\end{array}$ & $\begin{array}{c}-3.561^{* * *} \\
(0.430)\end{array}$ & $\begin{array}{c}-3.695^{* * *} \\
(0.362)\end{array}$ \\
\hline Age2 & $\begin{array}{c}0.032^{* * *} \\
(0.002)\end{array}$ & $\begin{array}{c}0.033^{* * *} \\
(0.002)\end{array}$ & $\begin{array}{c}0.035^{* * *} \\
(0.004)\end{array}$ & $\begin{array}{c}0.037^{* * *} \\
(0.003)\end{array}$ \\
\hline Compuls school & $\begin{array}{c}0.317 \\
(0.659)\end{array}$ & $\begin{array}{c}-0.170 \\
(0.337)\end{array}$ & $\begin{array}{c}0.835 \\
(1.148)\end{array}$ & $\begin{array}{l}-1.067 \\
(1.024)\end{array}$ \\
\hline High school & $\begin{array}{c}0.491 \\
(0.700)\end{array}$ & $\begin{array}{l}0.679 * \\
(0.404)\end{array}$ & $\begin{array}{c}1.061 \\
(1.246)\end{array}$ & $\begin{array}{c}-0.013 \\
(1.031)\end{array}$ \\
\hline College or higher & $\begin{array}{c}1.219 \\
(0.745)\end{array}$ & $\begin{array}{c}1.962^{* * *} \\
(0.460)\end{array}$ & $\begin{array}{c}1.679 \\
(1.277)\end{array}$ & $\begin{array}{c}1.745 \\
(1.128)\end{array}$ \\
\hline White collar & $\begin{array}{c}-0.213 \\
(0.175)\end{array}$ & $\begin{array}{c}0.036 \\
(0.171)\end{array}$ & $\begin{array}{l}-0.308 \\
(0.302)\end{array}$ & $\begin{array}{c}0.128 \\
(0.317)\end{array}$ \\
\hline Manager & $\begin{array}{c}0.684 \\
(0.582)\end{array}$ & $\begin{array}{c}0.509^{*} \\
(0.304)\end{array}$ & $\begin{array}{c}1.029 \\
(0.953)\end{array}$ & $\begin{array}{c}0.500 \\
(0.455)\end{array}$ \\
\hline Couple & $\begin{array}{c}-0.379^{* *} \\
(0.171)\end{array}$ & $\begin{array}{c}-0.510^{* *} \\
(0.208)\end{array}$ & $\begin{array}{c}-0.523^{*} \\
(0.304)\end{array}$ & $\begin{array}{l}-0.060 \\
(0.364)\end{array}$ \\
\hline Employed partner & $\begin{array}{c}0.023 \\
(0.156)\end{array}$ & $\begin{array}{c}0.118 \\
(0.130)\end{array}$ & $\begin{array}{c}0.164 \\
(0.280)\end{array}$ & $\begin{array}{c}0.275 \\
(0.218)\end{array}$ \\
\hline Log Finan w & $\begin{array}{l}-0.028 \\
(0.029)\end{array}$ & $\begin{array}{c}-0.083^{* * *} \\
(0.022)\end{array}$ & $\begin{array}{l}-0.001 \\
(0.040)\end{array}$ & $\begin{array}{c}-0.112^{* * *} \\
(0.041)\end{array}$ \\
\hline Log Real w & $\begin{array}{c}-0.013 \\
(0.031)\end{array}$ & $\begin{array}{c}0.028 \\
(0.025)\end{array}$ & $\begin{array}{c}0.005 \\
(0.060)\end{array}$ & $\begin{array}{c}0.100^{* *} \\
(0.048)\end{array}$ \\
\hline Retired & $\begin{array}{c}-1.210^{* * *} \\
(0.319)\end{array}$ & $\begin{array}{c}-2.578^{* * *} \\
(0.350)\end{array}$ & $\begin{array}{l}-1.106 \\
(0.919)\end{array}$ & $\begin{array}{c}-2.428^{* * *} \\
(0.693)\end{array}$ \\
\hline Reform 2004 & $\begin{array}{c}0.027 \\
(0.452)\end{array}$ & $\begin{array}{c}0.761^{* *} \\
(0.343)\end{array}$ & $\begin{array}{l}-0.765 \\
(1.037)\end{array}$ & $\begin{array}{c}1.013 \\
(0.651)\end{array}$ \\
\hline Eligible & $\begin{array}{c}-2.038^{* * *} \\
(0.252)\end{array}$ & $\begin{array}{c}-1.921^{* * *} \\
(0.242)\end{array}$ & $\begin{array}{c}-2.018^{* * *} \\
(0.534)\end{array}$ & $\begin{array}{c}-2.185^{* * *} \\
(0.377)\end{array}$ \\
\hline Obs & 2264 & 3810 & 829 & 1427 \\
\hline
\end{tabular}


Table 8: OLS

\begin{tabular}{|c|c|c|c|c|}
\hline Dep var: Ret age & $\begin{array}{l}\text { Women with } \\
\text { old \& low } \\
\text { edu parent }\end{array}$ & $\begin{array}{l}\text { Men with } \\
\text { old \& low } \\
\text { edu parent }\end{array}$ & $\begin{array}{l}\text { Women with } \\
\text { old \& low } \\
\text { occ parent }\end{array}$ & $\begin{array}{l}\text { Men with } \\
\text { old \& low } \\
\text { occ parent }\end{array}$ \\
\hline Imrate & $\begin{array}{c}15.801^{* *} \\
(7.611)\end{array}$ & $\begin{array}{c}0.318 \\
(8.098)\end{array}$ & $\begin{array}{c}17.850^{* *} \\
(7.964)\end{array}$ & $\begin{array}{l}-3.496 \\
(9.526)\end{array}$ \\
\hline OV & $\begin{array}{c}4.882^{* * *} \\
(1.152)\end{array}$ & $\begin{array}{c}9.113^{* * *} \\
(1.478)\end{array}$ & $\begin{array}{c}4.601^{* * *} \\
(1.170)\end{array}$ & $\begin{array}{c}10.018^{* * *} \\
(1.567)\end{array}$ \\
\hline Age & $\begin{array}{c}-3.435^{* * *} \\
(0.409)\end{array}$ & $\begin{array}{c}-3.735^{* * *} \\
(0.371)\end{array}$ & $\begin{array}{c}-3.563^{* * *} \\
(0.425)\end{array}$ & $\begin{array}{c}-3.759^{* * *} \\
(0.416)\end{array}$ \\
\hline Age2 & $\begin{array}{c}0.034^{* * *} \\
(0.004)\end{array}$ & $\begin{array}{c}0.037^{* * * *} \\
(0.003)\end{array}$ & $\begin{array}{c}0.035^{* * *} \\
(0.004)\end{array}$ & $\begin{array}{c}0.038^{* * *} \\
(0.004)\end{array}$ \\
\hline Compuls school & $\begin{array}{c}0.971 \\
(1.071)\end{array}$ & $\begin{array}{c}-0.983 \\
(1.028)\end{array}$ & $\begin{array}{c}1.521 \\
(0.955)\end{array}$ & $\begin{array}{c}-0.170 \\
(0.829)\end{array}$ \\
\hline High school & $\begin{array}{c}1.305 \\
(1.168)\end{array}$ & $\begin{array}{c}0.030 \\
(1.040)\end{array}$ & $\begin{array}{c}1.555 \\
(1.076)\end{array}$ & $\begin{array}{c}1.072 \\
(0.915)\end{array}$ \\
\hline College or higher & $\begin{array}{c}1.751 \\
(1.200)\end{array}$ & $\begin{array}{c}1.452 \\
(1.142)\end{array}$ & $\begin{array}{c}2.186^{* *} \\
(1.062)\end{array}$ & $\begin{array}{c}2.726^{* *} \\
(1.078)\end{array}$ \\
\hline White collar & $\begin{array}{l}-0.403 \\
(0.305)\end{array}$ & $\begin{array}{c}0.090 \\
(0.322)\end{array}$ & $\begin{array}{l}-0.244 \\
(0.353)\end{array}$ & $\begin{array}{c}0.026 \\
(0.337)\end{array}$ \\
\hline Manager & $\begin{array}{c}0.234 \\
(0.750)\end{array}$ & $\begin{array}{c}0.419 \\
(0.553)\end{array}$ & $\begin{array}{l}1.531^{*} \\
(0.880)\end{array}$ & $\begin{array}{c}0.193 \\
(0.619)\end{array}$ \\
\hline Couple & $\begin{array}{c}-0.629^{* *} \\
(0.311)\end{array}$ & $\begin{array}{l}-0.177 \\
(0.368)\end{array}$ & $\begin{array}{l}-0.609^{*} \\
(0.351)\end{array}$ & $\begin{array}{l}-0.480 \\
(0.372)\end{array}$ \\
\hline Employed partner & $\begin{array}{c}0.223 \\
(0.283)\end{array}$ & $\begin{array}{c}0.320 \\
(0.223)\end{array}$ & $\begin{array}{c}0.282 \\
(0.322)\end{array}$ & $\begin{array}{c}0.211 \\
(0.239)\end{array}$ \\
\hline Log Finan w & $\begin{array}{l}-0.023 \\
(0.039)\end{array}$ & $\begin{array}{c}-0.127^{* * *} \\
(0.040)\end{array}$ & $\begin{array}{c}0.019 \\
(0.041)\end{array}$ & $\begin{array}{c}-0.121^{* * *} \\
(0.041)\end{array}$ \\
\hline Log Real w & $\begin{array}{c}0.017 \\
(0.067)\end{array}$ & $\begin{array}{c}0.081^{*} \\
(0.047)\end{array}$ & $\begin{array}{c}0.005 \\
(0.063)\end{array}$ & $\begin{array}{c}0.114^{* *} \\
(0.052)\end{array}$ \\
\hline Retired & $\begin{array}{l}-1.451 \\
(0.986)\end{array}$ & $\begin{array}{c}-2.526^{* * *} \\
(0.674)\end{array}$ & $\begin{array}{c}-0.824 \\
(1.039)\end{array}$ & $\begin{array}{c}-2.735^{* * *} \\
(0.800)\end{array}$ \\
\hline Reform 2004 & $\begin{array}{c}-0.867 \\
(1.060)\end{array}$ & $\begin{array}{c}1.164^{*} \\
(0.660)\end{array}$ & $\begin{array}{l}-1.550 \\
(1.064)\end{array}$ & $\begin{array}{c}1.431^{* *} \\
(0.695)\end{array}$ \\
\hline Eligible & $\begin{array}{c}-1.484^{* * *} \\
(0.519)\end{array}$ & $\begin{array}{c}-2.071^{* * *} \\
(0.363)\end{array}$ & $\begin{array}{c}-1.801^{* * * *} \\
(0.633)\end{array}$ & $\begin{array}{c}-1.691^{* * * *} \\
(0.479)\end{array}$ \\
\hline Obs & 752 & 1309 & 622 & 1115 \\
\hline
\end{tabular}

Note: all specifications include regional, and size of the municipalities fixed effects.

Standard errors in parenthesis clustered by region*year, significance: $(*)$ if $\mathrm{p}<.1,(* *)$ if $\mathrm{p}<.05,(* * *)$ if $\mathrm{p}<.01$. 
Table 9: IV

\begin{tabular}{|c|c|c|c|c|}
\hline Dep var: Ret age & Women & Men & $\begin{array}{l}\text { Wom with } \\
\text { old parent }\end{array}$ & $\begin{array}{l}\text { Men with } \\
\text { old parent }\end{array}$ \\
\hline Imrate & $\begin{array}{c}10.275^{* * *} \\
(3.811)\end{array}$ & $\begin{array}{c}5.835 \\
(4.916)\end{array}$ & $\begin{array}{c}15.776^{* *} \\
(7.558)\end{array}$ & $\begin{array}{c}2.128 \\
(8.517)\end{array}$ \\
\hline OV & $\begin{array}{c}5.227^{* * *} \\
(0.533)\end{array}$ & $\begin{array}{c}7.909^{* * *} \\
(0.739)\end{array}$ & $\begin{array}{c}4.801^{* * *} \\
(0.995)\end{array}$ & $\begin{array}{c}9.252^{* * *} \\
(1.445)\end{array}$ \\
\hline Age & $\begin{array}{c}-3.189^{* * *} \\
(0.237)\end{array}$ & $\begin{array}{c}-3.345^{* * *} \\
(0.163)\end{array}$ & $\begin{array}{c}-3.568^{* * *} \\
(0.419)\end{array}$ & $\begin{array}{c}-3.697^{* * *} \\
(0.355)\end{array}$ \\
\hline Age2 & $\begin{array}{c}0.032^{* * *} \\
(0.002)\end{array}$ & $\begin{array}{c}0.033^{* * *} \\
(0.001)\end{array}$ & $\begin{array}{c}0.035^{* * *} \\
(0.004)\end{array}$ & $\begin{array}{c}0.037^{* * *} \\
(0.003)\end{array}$ \\
\hline Compuls school & $\begin{array}{c}0.306 \\
(0.648)\end{array}$ & $\begin{array}{l}-0.168 \\
(0.334)\end{array}$ & $\begin{array}{c}0.829 \\
(1.117)\end{array}$ & $\begin{array}{l}-1.095 \\
(1.003)\end{array}$ \\
\hline High school & $\begin{array}{c}0.475 \\
(0.689)\end{array}$ & $\begin{array}{l}0.681^{*} \\
(0.400)\end{array}$ & $\begin{array}{c}1.049 \\
(1.213)\end{array}$ & $\begin{array}{l}-0.040 \\
(1.010)\end{array}$ \\
\hline College or higher & $\begin{array}{c}1.202 \\
(0.732)\end{array}$ & $\begin{array}{c}1.963^{* * *} \\
(0.456)\end{array}$ & $\begin{array}{c}1.670 \\
(1.242)\end{array}$ & $\begin{array}{c}1.725 \\
(1.107)\end{array}$ \\
\hline White collar & $\begin{array}{l}-0.211 \\
(0.172)\end{array}$ & $\begin{array}{c}0.036 \\
(0.170)\end{array}$ & $\begin{array}{l}-0.306 \\
(0.294)\end{array}$ & $\begin{array}{c}0.123 \\
(0.312)\end{array}$ \\
\hline Manager & $\begin{array}{c}0.687 \\
(0.575)\end{array}$ & $\begin{array}{l}0.508^{*} \\
(0.302)\end{array}$ & $\begin{array}{l}1.035 \\
(0.925)\end{array}$ & $\begin{array}{c}0.505 \\
(0.447)\end{array}$ \\
\hline Couple & $\begin{array}{c}-0.377^{* *} \\
(0.170)\end{array}$ & $\begin{array}{c}-0.511^{* *} \\
(0.207)\end{array}$ & $\begin{array}{c}-0.506^{*} \\
(0.297)\end{array}$ & $\begin{array}{l}-0.047 \\
(0.359)\end{array}$ \\
\hline Employed partner & $\begin{array}{c}0.022 \\
(0.154)\end{array}$ & $\begin{array}{c}0.119 \\
(0.129)\end{array}$ & $\begin{array}{c}0.162 \\
(0.272)\end{array}$ & $\begin{array}{c}0.266 \\
(0.214)\end{array}$ \\
\hline Log Finan w & $\begin{array}{l}-0.027 \\
(0.029)\end{array}$ & $\begin{array}{c}-0.083^{* * *} \\
(0.021)\end{array}$ & $\begin{array}{c}0.001 \\
(0.039)\end{array}$ & $\begin{array}{c}-0.112^{* * *} \\
(0.040)\end{array}$ \\
\hline Log Real w & $\begin{array}{c}-0.014 \\
(0.030)\end{array}$ & $\begin{array}{c}0.028 \\
(0.025)\end{array}$ & $\begin{array}{c}0.002 \\
(0.059)\end{array}$ & $\begin{array}{c}0.097^{* *} \\
(0.048)\end{array}$ \\
\hline Retired & $\begin{array}{c}-1.220^{* * *} \\
(0.311)\end{array}$ & $\begin{array}{c}-2.577^{* * *} \\
(0.347)\end{array}$ & $\begin{array}{l}-1.125 \\
(0.887)\end{array}$ & $\begin{array}{c}-2.441^{* * *} \\
(0.677)\end{array}$ \\
\hline Reform 2004 & $\begin{array}{c}0.023 \\
(0.443)\end{array}$ & $\begin{array}{c}0.763^{* *} \\
(0.338)\end{array}$ & $\begin{array}{l}-0.790 \\
(0.998)\end{array}$ & $\begin{array}{c}0.994 \\
(0.631)\end{array}$ \\
\hline Eligible & $\begin{array}{c}-2.040^{* * *} \\
(0.248)\end{array}$ & $\begin{array}{c}-1.921^{* * *} \\
(0.240)\end{array}$ & $\begin{array}{c}-2.011^{* * *} \\
(0.522)\end{array}$ & $\begin{array}{c}-2.174^{* * *} \\
(0.369)\end{array}$ \\
\hline $\begin{array}{l}\text { First Stage } \\
\text { IV }\end{array}$ & $\begin{array}{c}1.007^{* * *} \\
(0.069)\end{array}$ & $\begin{array}{c}0.918^{* * *} \\
(0.072)\end{array}$ & $\begin{array}{c}0.992^{* * *} \\
(0.079)\end{array}$ & $\begin{array}{c}0.937^{* * *} \\
(0.075)\end{array}$ \\
\hline $\begin{array}{l}\text { Kleibergen-Paap rk } \\
\text { Wald F statistic }\end{array}$ & 213.025 & 162.356 & 159.075 & 155.552 \\
\hline Obs & 2264 & 3810 & 829 & 1427 \\
\hline
\end{tabular}

Note: all specifications include regional, and size of the municipalities fixed effects.

Standard errors in parenthesis clustered by region*year, significance: $\left(^{*}\right)$ if $\mathrm{p}<.1,(* *)$ if $\mathrm{p}<.05,(* * *)$ if $\mathrm{p}<.01$. 
Table 10: IV

\begin{tabular}{|c|c|c|c|c|}
\hline Dep var: Ret age & $\begin{array}{l}\text { Women with } \\
\text { old \& low } \\
\text { edu parent }\end{array}$ & $\begin{array}{l}\text { Men with } \\
\text { old \& low } \\
\text { edu parent }\end{array}$ & $\begin{array}{l}\text { Women with } \\
\text { old \& low } \\
\text { occ parent }\end{array}$ & $\begin{array}{l}\text { Men with } \\
\text { old \& low } \\
\text { occ parent }\end{array}$ \\
\hline Imrate & $\begin{array}{c}19.484^{* *} \\
(8.046)\end{array}$ & $\begin{array}{c}1.614 \\
(8.309)\end{array}$ & $\begin{array}{c}23.418^{* * *} \\
(8.424)\end{array}$ & $\begin{array}{l}-0.820 \\
(9.716)\end{array}$ \\
\hline OV & $\begin{array}{c}4.747^{* * *} \\
(1.099)\end{array}$ & $\begin{array}{c}9.061^{* * *} \\
(1.469)\end{array}$ & $\begin{array}{c}4.416^{* * *} \\
(1.105)\end{array}$ & $\begin{array}{c}9.897^{* * *} \\
(1.553)\end{array}$ \\
\hline Age & $\begin{array}{c}-3.450^{* * *} \\
(0.398)\end{array}$ & $\begin{array}{c}-3.734^{* * *} \\
(0.363)\end{array}$ & $\begin{array}{c}-3.587^{* * *} \\
(0.416)\end{array}$ & $\begin{array}{c}-3.759 * * * \\
(0.407)\end{array}$ \\
\hline Age2 & $\begin{array}{c}0.034^{* * *} \\
(0.004)\end{array}$ & $\begin{array}{c}0.037^{* * *} \\
(0.003)\end{array}$ & $\begin{array}{c}0.035^{* * *} \\
(0.004)\end{array}$ & $\begin{array}{c}0.037^{* * *} \\
(0.004)\end{array}$ \\
\hline Compuls school & $\begin{array}{c}0.961 \\
(1.041)\end{array}$ & $\begin{array}{c}-0.998 \\
(1.007)\end{array}$ & $\begin{array}{c}1.478 \\
(0.936)\end{array}$ & $\begin{array}{l}-0.200 \\
(0.807)\end{array}$ \\
\hline High school & $\begin{array}{c}1.288 \\
(1.137)\end{array}$ & $\begin{array}{c}0.016 \\
(1.017)\end{array}$ & $\begin{array}{c}1.501 \\
(1.056)\end{array}$ & $\begin{array}{c}1.044 \\
(0.890)\end{array}$ \\
\hline College or higher & $\begin{array}{c}1.738 \\
(1.168)\end{array}$ & $\begin{array}{c}1.440 \\
(1.119)\end{array}$ & $\begin{array}{l}2.136^{* *} \\
(1.041)\end{array}$ & $\begin{array}{l}2.707^{* *} \\
(1.052)\end{array}$ \\
\hline White collar & $\begin{array}{l}-0.400 \\
(0.296)\end{array}$ & $\begin{array}{c}0.087 \\
(0.316)\end{array}$ & $\begin{array}{l}-0.239 \\
(0.339)\end{array}$ & $\begin{array}{c}0.020 \\
(0.330)\end{array}$ \\
\hline Manager & $\begin{array}{c}0.244 \\
(0.732)\end{array}$ & $\begin{array}{c}0.424 \\
(0.541)\end{array}$ & $\begin{array}{l}1.548^{*} \\
(0.870)\end{array}$ & $\begin{array}{c}0.200 \\
(0.607)\end{array}$ \\
\hline Couple & $\begin{array}{c}-0.604^{* *} \\
(0.303)\end{array}$ & $\begin{array}{l}-0.171 \\
(0.362)\end{array}$ & $\begin{array}{l}-0.564 \\
(0.343)\end{array}$ & $\begin{array}{l}-0.466 \\
(0.366)\end{array}$ \\
\hline Employed partner & $\begin{array}{c}0.217 \\
(0.273)\end{array}$ & $\begin{array}{c}0.316 \\
(0.219)\end{array}$ & $\begin{array}{c}0.271 \\
(0.311)\end{array}$ & $\begin{array}{c}0.204 \\
(0.234)\end{array}$ \\
\hline Log Finan w & $\begin{array}{l}-0.021 \\
(0.037)\end{array}$ & $\begin{array}{c}-0.127^{* * *} \\
(0.039)\end{array}$ & $\begin{array}{c}0.021 \\
(0.039)\end{array}$ & $\begin{array}{c}-0.121^{* * *} \\
(0.040)\end{array}$ \\
\hline Log Real w & $\begin{array}{l}0.015 \\
(0.064)\end{array}$ & $\begin{array}{l}0.080^{*} \\
(0.047)\end{array}$ & $\begin{array}{c}0.000 \\
(0.060)\end{array}$ & $\begin{array}{c}0.112^{* *} \\
(0.051)\end{array}$ \\
\hline Retired & $\begin{array}{l}-1.467 \\
(0.946)\end{array}$ & $\begin{array}{c}-2.530^{* * *} \\
(0.658)\end{array}$ & $\begin{array}{l}-0.836 \\
(0.978)\end{array}$ & $\begin{array}{c}-2.739 * * * \\
(0.777)\end{array}$ \\
\hline Reform 2004 & $\begin{array}{l}-0.913 \\
(1.015)\end{array}$ & $\begin{array}{l}1.152^{*} \\
(0.643)\end{array}$ & $\begin{array}{l}-1.638 \\
(1.005)\end{array}$ & $\begin{array}{c}1.405^{* *} \\
(0.672)\end{array}$ \\
\hline Eligible & $\begin{array}{c}-1.471^{* * * *} \\
(0.506)\end{array}$ & $\begin{array}{c}-2.065^{* * * *} \\
(0.354) \\
\end{array}$ & $\begin{array}{c}-1.769^{* * *} \\
(0.611)\end{array}$ & $\begin{array}{c}-1.687^{* * * *} \\
(0.467) \\
\end{array}$ \\
\hline $\begin{array}{l}\text { First Stage } \\
\text { IV }\end{array}$ & $\begin{array}{c}0.985^{* * *} \\
(0.080)\end{array}$ & $\begin{array}{c}0.938^{* * *} \\
(0.075)\end{array}$ & $\begin{array}{c}0.989^{* * *} \\
(0.079)\end{array}$ & $\begin{array}{c}0.953^{* * *} \\
(0.075)\end{array}$ \\
\hline $\begin{array}{l}\text { Kleibergen-Paap rk } \\
\text { Wald F statistic }\end{array}$ & 150.239 & 157.196 & 157.758 & 160.776 \\
\hline Obs & 752 & 1309 & 622 & 1115 \\
\hline
\end{tabular}

Note: all specifications include regional, and size of the municipalities fixed effects.

Standard errors in parenthesis clustered by region*year, significance: $(*)$ if $\mathrm{p}<.1,(* *)$ if $\mathrm{p}<.05,(* * *)$ if $\mathrm{p}<.01$. 
Figure 1: Old dependency ratio.

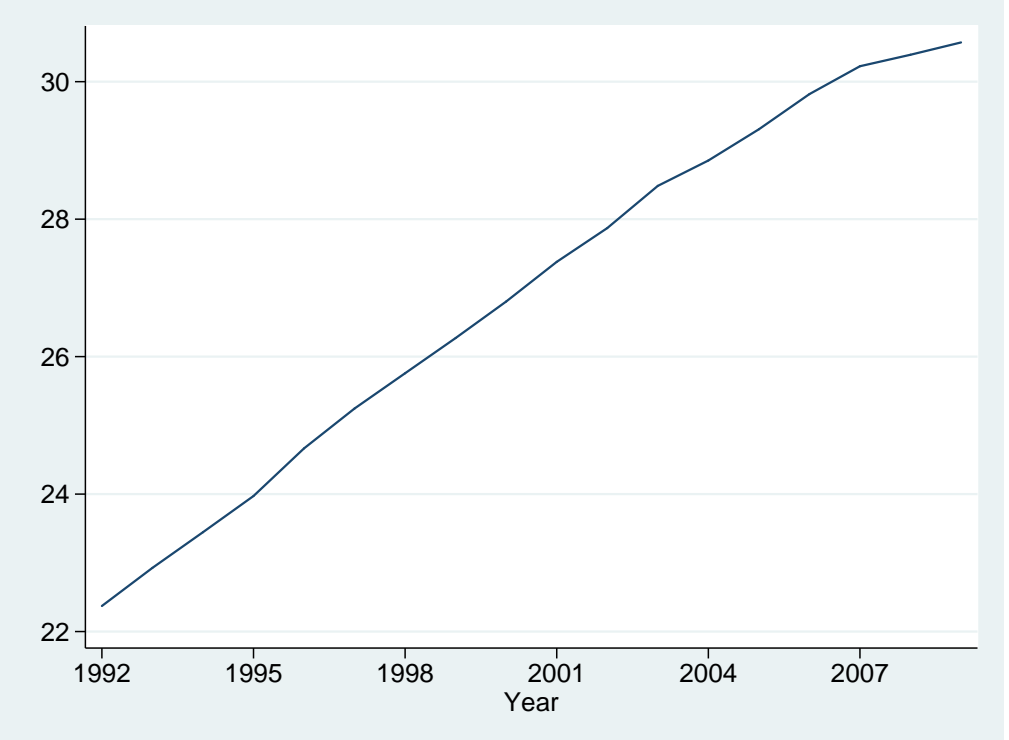

Source: authors' calculation from registry data.

Figure 2: Immigration rate: resident population.

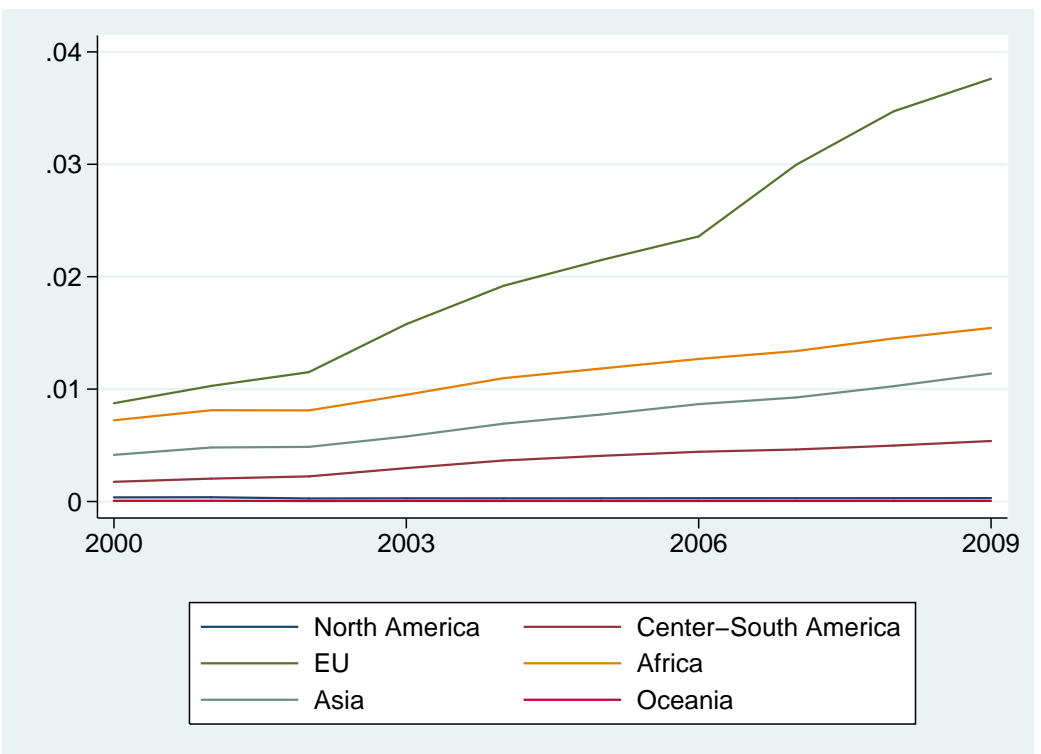

Source: authors' calculation from registry data. 
Figure 3: Domestic workers: share by immigration status.

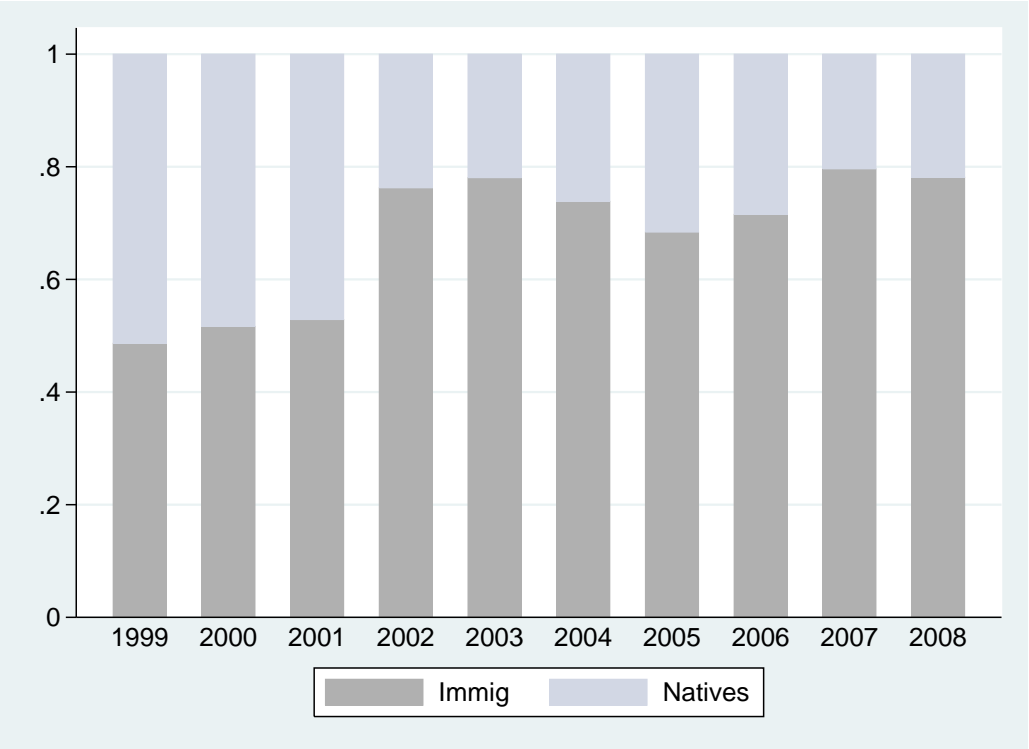

Source: INPS (1999-2008). 
Our papers can be downloaded at:

http://cerp.unito.it/index.php/en/publications

\section{CeRP Working Paper Series}

\begin{tabular}{|c|c|}
\hline $\mathrm{N}^{\circ} 124 / 11$ & $\begin{array}{l}\text { Agnese Romiti } \\
\text { Mariacristina Rossi }\end{array}$ \\
\hline$N^{\circ} 123 / 11$ & $\begin{array}{l}\text { Elsa Fornero } \\
\text { Maria Cristina Rossi } \\
\text { Maria Cesira Urzì Branca }\end{array}$ \\
\hline$N^{\circ} 122 / 11$ & Serena Trucchi \\
\hline$N^{\circ} 121 / 11$ & $\begin{array}{l}\text { Elsa Fornero } \\
\text { Chiara Monticone } \\
\text { Serena Trucchi }\end{array}$ \\
\hline$N^{\circ} 120 / 11$ & $\begin{array}{l}\text { Giovanni Mastrobuoni } \\
\text { Filippo Taddei }\end{array}$ \\
\hline$N^{\circ} 119 / 11$ & $\begin{array}{l}\text { Maarten van Rooij } \\
\text { Annamaria Lusardi } \\
\text { Rob Alessie }\end{array}$ \\
\hline $\mathrm{N}^{\circ} 118 / 11$ & $\begin{array}{l}\text { Luca Beltrametti } \\
\text { Matteo Della Valle }\end{array}$ \\
\hline $\mathrm{N}^{\circ} 117 / 11$ & $\begin{array}{l}\text { Riccardo Calcagno } \\
\text { Chiara Monticone }\end{array}$ \\
\hline$N^{\circ} 116 / 11$ & $\begin{array}{l}\text { Annamaria Lusardi } \\
\text { Daniel Schneider } \\
\text { Peter Tufano }\end{array}$ \\
\hline$N^{\circ} 115 / 11$ & $\begin{array}{l}\text { Adele Atkinson } \\
\text { Flore-Anne Messy }\end{array}$ \\
\hline$N^{\circ} 114 / 11$ & $\begin{array}{l}\text { Leora Klapper } \\
\text { Georgios A. Panos }\end{array}$ \\
\hline$N^{\circ} 113 / 11$ & $\begin{array}{l}\text { Diana Crossan } \\
\text { David Feslier } \\
\text { Roger Hurnard }\end{array}$ \\
\hline$N^{\circ} 112 / 11$ & $\begin{array}{l}\text { Johan Almenberg } \\
\text { Jenny Säve-Söderbergh }\end{array}$ \\
\hline$N^{\circ} 111 / 11$ & $\begin{array}{l}\text { Elsa Fornero } \\
\text { Chiara Monticone }\end{array}$ \\
\hline $\mathrm{N}^{\circ} 110 / 11$ & $\begin{array}{l}\text { Rob Alessie } \\
\text { Maarten Van Rooij } \\
\text { Annamaria Lusardi }\end{array}$ \\
\hline$N^{\circ} 109 / 11$ & $\begin{array}{l}\text { Tabea Bucher-Koenen } \\
\text { Annamaria Lusardi }\end{array}$ \\
\hline$N^{\circ} 108 / 11$ & Shizuka Sekita \\
\hline$N^{\circ} 107 / 11$ & $\begin{array}{l}\text { Annamaria Lusardi } \\
\text { Olivia S. Mitchell }\end{array}$ \\
\hline
\end{tabular}

Should we Retire Earlier in order to Look After our Parents? The Role of immigrants

Explaining why, right or wrong, (Italian) households do not like reverse mortgages

How credit markets affect homeownership: an explanation based on differences between Italian regions

The effect of financial literacy on mortgage choices

Age Before Beauty? Productivity and Work vs. Seniority and Early Retirement

Financial Literacy, Retirement Planning, and Household Wealth

Does the implicit pension debt mean anything after all?

Financial Literacy and the Demand for Financial Advice

Financially Fragile Households: Evidence and Implications

Assessing financial literacy in 12 countries: an OECD Pilot Exercise

Financial Literacy and Retirement Planning in View of a Growing Youth Demographic: The Russian Case

Financial Literacy and Retirement Planning in New Zealand

Financial Literacy and Retirement Planning in Sweden

Financial Literacy and Pension Plan Participation in Italy

Financial Literacy, Retirement Preparation and Pension

Expectations in the Netherlands

Financial Literacy and Retirement Planning in Germany

Financial Literacy and Retirement Planning in Japan

Financial Literacy and Retirement Planning in the United States 


\begin{tabular}{|c|c|}
\hline $\mathrm{N}^{\circ} 106 / 11$ & $\begin{array}{l}\text { Annamaria Lusardi } \\
\text { Olivia S. Mitchell }\end{array}$ \\
\hline $\mathrm{N}^{\circ} 105 / 11$ & Agnese Romiti \\
\hline $\mathrm{N}^{\circ} 104 / 11$ & Ambrogio Rinaldi \\
\hline $\mathrm{N}^{\circ} 103 / 10$ & $\begin{array}{l}\text { Fabio Bagliano } \\
\text { Claudio Morana }\end{array}$ \\
\hline$N^{\circ} 102 / 10$ & $\begin{array}{l}\text { Nuno Cassola } \\
\text { Claudio Morana }\end{array}$ \\
\hline $\mathrm{N}^{\circ} 101 / 10$ & Tetyana Dubovyk \\
\hline $\mathrm{N}^{\circ} 100 / 10$ & $\begin{array}{l}\text { Laura Piatti } \\
\text { Giuseppe Rocco }\end{array}$ \\
\hline$N^{\circ} 99 / 10$ & $\begin{array}{l}\text { Fabio Bagliano } \\
\text { Claudio Morana }\end{array}$ \\
\hline$N^{\circ} 98 / 10$ & $\begin{array}{l}\text { Annamaria Lusardi } \\
\text { Daniel Schneider } \\
\text { Peter Tufano }\end{array}$ \\
\hline$N^{\circ} 97 / 10$ & $\begin{array}{l}\text { Carlo Maccheroni } \\
\text { Tiziana Barugola }\end{array}$ \\
\hline$N^{\circ} 96 / 10$ & $\begin{array}{l}\text { Riccardo Calcagno } \\
\text { Mariacristina Rossi }\end{array}$ \\
\hline$N^{\circ} 95 / 10$ & $\begin{array}{l}\text { Flavia Coda Moscarola } \\
\text { Elsa Fornero } \\
\text { Mariacristina Rossi }\end{array}$ \\
\hline$N^{\circ} 94 / 10$ & $\begin{array}{l}\text { John A. List } \\
\text { Sally Sadoff } \\
\text { Mathis Wagner }\end{array}$ \\
\hline$N^{\circ} 93 / 10$ & Mathis Wagner \\
\hline$N^{\circ} 92 / 10$ & $\begin{array}{l}\text { Rob Alessie } \\
\text { Michele Belloni }\end{array}$ \\
\hline$N^{\circ} 91 / 09$ & $\begin{array}{l}\text { Annamaria Lusardi } \\
\text { Olivia S. Mitchell } \\
\text { Vilsa Curto }\end{array}$ \\
\hline$N^{\circ} 90 / 09$ & $\begin{array}{l}\text { Annamaria Lusardi } \\
\text { Olivia S. Mitchell }\end{array}$ \\
\hline$N^{\circ} 89 / 09$ & Elena Vigna \\
\hline
\end{tabular}

$\begin{array}{ll}\mathrm{N}^{\circ} 88 / 09 & \text { Maela Giofré } \\ \mathrm{N}^{\circ} 87 / 09 & \begin{array}{l}\text { Elsa Fornero } \\ \text { Annamaria Lusardi } \\ \text { Chiara Monticone }\end{array} \\ & \text { Margherita Borella } \\ & \text { Flavia Coda Moscarola }\end{array}$

Financial Literacy Around the World: An Overview

Immigrants-Natives Complementarities in Production: Evidence from Italy

Pension awareness and nation-wide auto-enrolment: the Italian experience

The Great Recession: US dynamics and spillovers to the world economy

The 2007-? financial crisis: a money market perspective

Macroeconomic Aspects of Italian Pension Reforms of 1990s

L’educazione e la comunicazione previdenziale - Il caso italiano

The effects of US economic and financial crises on euro area convergence

The Economic Crisis and Medical Care Usage

E se l'aspettativa di vita continuasse la sua crescita? Alcune ipotesi per le generazioni italiane 1950-2005

Portfolio Choice and Precautionary Savings

Parents/children “deals”: Inter-Vivos Transfers and Living Proximity

So you want to run an experiment, now what? Some Simple Rules of Thumb for Optimal Experimental Design

The Heterogeneous Labor Market Effects of Immigration

Retirement choices in Italy: what an option value model tells us

Financial Literacy among the Young:

Evidence and Implications for Consumer Policy

How Ordinary Consumers Make Complex Economic Decisions: Financial Literacy and Retirement Readiness

Mean-variance inefficiency of CRRA and CARA utility functions for portfolio selection in defined contribution pension schemes

Convergence of EMU Equity Portfolios

Adequacy of Saving for Old Age in Europe

Microsimulation of Pension Reforms: Behavioural versus Nonbehavioural Approach 


\begin{tabular}{|c|c|}
\hline$N^{\circ} 85 / 09$ & $\begin{array}{l}\text { Cathal O’Donoghue } \\
\text { John Lennon } \\
\text { Stephen Hynes }\end{array}$ \\
\hline$N-84 / 09$ & \\
\hline$N^{\circ} 83 / 09$ & $\begin{array}{l}\text { Annamaria Lusardi } \\
\text { Peter Tufano }\end{array}$ \\
\hline$N^{\circ} 82 / 09$ & $\begin{array}{l}\text { Carolina Fugazza } \\
\text { Massimo Guidolin } \\
\text { Giovanna Nicodano }\end{array}$ \\
\hline$N^{\circ} 81 / 09$ & $\begin{array}{l}\text { Fabio Bagliano } \\
\text { Claudio Morana }\end{array}$ \\
\hline$N^{\circ} 80 / 08$ & Claudio Campanale \\
\hline$N^{\circ} 79 / 08$ & Annamaria Lusardi \\
\hline $\mathrm{N}^{\circ} 78 / 08$ & $\begin{array}{l}\text { Margherita Borella } \\
\text { Giovanna Segre }\end{array}$ \\
\hline$N^{\circ} 77 / 08$ & $\begin{array}{l}\text { Giovanni Guazzarotti } \\
\text { Pietro Tommasino }\end{array}$ \\
\hline$N^{\circ} 76 / 08$ & $\begin{array}{l}\text { Riccardo Calcagno } \\
\text { Elsa Fornero } \\
\text { Mariacristina Rossi }\end{array}$ \\
\hline$N^{\circ} 75 / 08$ & $\begin{array}{l}\text { Harold Alderman } \\
\text { Johannes Hoogeveen } \\
\text { Mariacristina Rossi }\end{array}$ \\
\hline$N^{\circ} 74 / 08$ & Maela Giofré \\
\hline$N^{\circ} 73 / 08$ & $\begin{array}{l}\text { Michele Belloni } \\
\text { Rob Alessie }\end{array}$ \\
\hline$N^{\circ} 72 / 08$ & $\begin{array}{l}\text { Annamaria Lusardi } \\
\text { Olivia Mitchell }\end{array}$ \\
\hline$N^{\circ} 71 / 07$ & Flavia Coda Moscarola \\
\hline
\end{tabular}

N 70/07 Radha Iyengar Giovanni Mastrobuoni

$\begin{array}{ll}\mathrm{N}^{\circ} 69 / 07 & \begin{array}{l}\text { Carolina Fugazza } \\ \text { Massimo Guidolin } \\ \text { Giovanna Nicodano }\end{array} \\ \mathrm{N}^{\circ} 68 / 07 & \begin{array}{l}\text { Massimo Guidolin } \\ \text { Giovanna Nicodano }\end{array} \\ \mathrm{N}^{\circ} \text { 67/07 } & \begin{array}{l}\text { Carolina Fugazza } \\ \text { Maela Giofré } \\ \text { Giovanna Nicodano }\end{array}\end{array}$

N 66/07 Maarten van Rooij Annamaria Lusardi
The Life-Cycle Income Analysis Model (LIAM): A Study of a Flexible Dynamic Microsimulation Modelling Computing Framework

Il sistema previdenziale italiano dallo shock petrolifero del 1973 al Trattato di Maastricht del 1993

Debt Literacy, Financial Experiences, and Overindebtedness

Time and Risk Diversification in Real Estate Investments: Assessing the Ex Post Economic Value

Permanent and Transitory Dynamics in House Prices and Consumption: Cross-Country Evidence

Learning, Ambiguity and Life-Cycle Portfolio Allocation

Increasing the Effectiveness of Financial Education in the Workplace

Le pensioni dei lavoratori parasubordinati: prospettive dopo un decennio di gestione separata

The Annuity Market in an Evolving Pension System: Lessons from Italy

The Effect of House Prices on Household Saving: The Case of Italy

Preschool Nutrition and Subsequent Schooling Attainment: Longitudinal Evidence from Tanzania

Information Asymmetries and Foreign Equity Portfolios: Households versus Financial Investors

The Importance of Financial Incentives on Retirement Choices: New Evidence for Italy

Planning and Financial Literacy: How Do Women Fare?

Women participation and caring decisions: do different institutional frameworks matter? A comparison between Italy and The Netherlands

The Political Economy of the Disability Insurance. Theory and Evidence of Gubernatorial Learning from Social Security Administration Monitoring

Investing in Mixed Asset Portfolios: the Ex-Post Performance

Small Caps in International Diversified Portfolios

International Diversification and Labor Income Risk

Financial Literacy and Stock Market Participation 
Rob Alessie

N 65/07 Annamaria Lusardi

N 64/07 Carlo Casarosa

Luca Spataro

N 63/07 Claudio Campanale

N 62/07 Margherita Borella

Elsa Fornero

Mariacristina Rossi

N 61/07 Irina Kovrova

N 60/07 Riccardo Cesari

Giuseppe Grande

Fabio Panetta

N ${ }^{\circ}$ 59/07 Riccardo Calcagno

Roman Kraeussl

Chiara Monticone

N ${ }^{\circ}$ 58/07 Elisa Luciano

Jaap Spreeuw

Elena Vigna

$\mathrm{N}^{\circ} 57 / 07$

Giovanni Mastrobuoni

Matthew Weinberg

N ${ }^{\circ}$ 56/07 John A. Turner

Satyendra Verma

No 55/06 Antonio Abatemarco

N 54/06 Annamaria Lusardi

Olivia S. Mitchell

N 53/06 Giovanni Mastrobuoni

N 52/06 Luigi Guiso

Tullio Jappelli

N 51/06 Giovanni Mastrobuoni

N ${ }^{\circ} 50 / 06 \quad$ Andrea Buffa

Chiara Monticone

N 49/06 Mariacristina Rossi

$\mathrm{N}^{\circ}$ 48/06 Onorato Castellino

Elsa Fornero

$\mathrm{N}^{\circ}$ 47/06 Michele Belloni

Carlo Maccheroni

$\mathrm{N}^{\circ}$ 46/05 Annamaria Lusardi Olivia S. Mitchell

$\mathrm{N}^{\circ} 45 / 05 \quad$ Claudio Campanale
Household Saving Behavior: The Role of Literacy, Information and Financial Education Programs

(Updated version June 08: "Financial Literacy: An Essential Tool for Informed Consumer Choice?”)

Rate of Growth of Population, Saving and Wealth in the Basic

Life-cycle Model when the Household is the Decision Unit

Life-Cycle Portfolio Choice: The Role of Heterogeneous UnderDiversification

Does Consumption Respond to Predicted Increases in Cash-onhand Availability? Evidence from the Italian "Severance Pay"

Effects of the Introduction of a Funded Pillar on the Russian Household Savings: Evidence from the 2002 Pension Reform

La Previdenza Complementare in Italia:

Caratteristiche, Sviluppo e Opportunità per i Lavoratori

An Analysis of the Effects of the Severance Pay Reform on Credit to Italian SMEs

Modelling Stochastic Mortality for Dependent Lives

Heterogeneity in Intra-Monthly Consumption. Patterns, SelfControl, and Savings at Retirement

Why Some Workers Don’t Take 401(k) Plan Offers: Inertia versus Economics

On the Measurement of Intra-Generational Lifetime Redistribution in Pension Systems

Baby Boomer Retirement Security: The Roles of Planning, Financial Literacy, and Housing Wealth

Labor Supply Effects of the Recent Social Security Benefit Cuts: Empirical Estimates Using Cohort Discontinuities

Information Acquisition and Portfolio Performance

The Social Security Earnings Test Removal. Money Saved or Money Spent by the Trust Fund?

Do European Pension Reforms Improve the Adequacy of Saving?

Examining the Interaction between Saving and Contributions to Personal Pension Plans. Evidence from the BHPS

Public Policy and the Transition to Private Pension Provision in the United States and Europe

Actuarial Neutrality when Longevity Increases: An Application to the Italian Pension System

Financial Literacy and Planning: Implications for Retirement Wellbeing

Increasing Returns to Savings and Wealth Inequality 


\begin{tabular}{|c|c|}
\hline$N^{\circ} 44 / 05$ & Henrik Cronqvist \\
\hline \multirow[t]{4}{*}{$N^{\circ} 43 / 05$} & John Beshears \\
\hline & James J. Choi \\
\hline & David Laibson \\
\hline & Brigitte C. Madrian \\
\hline \multirow[t]{2}{*}{$N^{\circ} 42 / 05$} & Margherita Borella \\
\hline & Flavia Coda Moscarol \\
\hline \multirow[t]{2}{*}{$N^{\circ} 41 / 05$} & Massimo Guidolin \\
\hline & Giovanna Nicodano \\
\hline \multirow[t]{3}{*}{$N^{\circ} 40 / 05$} & Carolina Fugazza \\
\hline & Massimo Guidolin \\
\hline & Giovanna Nicodano \\
\hline$N^{\circ} 39 / 05$ & Anna Rita Bacinello \\
\hline \multirow[t]{2}{*}{$N^{\circ} 38 / 05$} & Carolina Fugazza \\
\hline & Federica Teppa \\
\hline$N^{\circ} 37 / 04$ & Jay Ginn \\
\hline$N^{\circ} 36 / 04$ & Laurence J. Kotlikoff \\
\hline \multirow[t]{3}{*}{$N^{\circ} 35 / 04$} & Monika Bütler \\
\hline & Olivia Huguenin \\
\hline & Federica Teppa \\
\hline$N^{\circ} 34 / 04$ & Chourouk Houssi \\
\hline \multirow[t]{3}{*}{$N^{\circ} 33 / 04$} & Elsa Fornero \\
\hline & Carolina Fugazza \\
\hline & Giacomo Ponzetto \\
\hline \multirow[t]{2}{*}{$N^{\circ} 32 / 04$} & Angelo Marano \\
\hline & Paolo Sestito \\
\hline$N^{\circ} 31 / 03$ & Giacomo Ponzetto \\
\hline \multirow[t]{2}{*}{$N^{\circ} 30 / 03$} & Bas Arts \\
\hline & Elena Vigna \\
\hline$N^{\circ} 29 / 02$ & Marco Taboga \\
\hline$N^{\circ} 28 / 02$ & Luca Spataro \\
\hline$N^{\circ} 27 / 02$ & Reinhold Schnabel \\
\hline$N^{\circ} 26 / 02$ & E. Philip Davis \\
\hline$N^{\circ} 25 / 02$ & Edmund Cannon \\
\hline & Ian Tonks \\
\hline$N^{\circ} 24 / 02$ & Laura Ballotta \\
\hline & Steven Haberman \\
\hline$N^{\circ} 23 / 02$ & Ermanno Pitacco \\
\hline
\end{tabular}

\section{Advertising and Portfolio Choice}

The Importance of Default Options for Retirement Saving Outcomes: Evidence from the United States

Distributive Properties of Pensions Systems: a Simulation of the Italian Transition from Defined Benefit to Defined Contribution Small Caps in International Equity Portfolios: The Effects of Variance Risk.

Investing for the Long-Run in European Real Estate. Does Predictability Matter?

Modelling the Surrender Conditions in Equity-Linked Life Insurance

An Empirical Assessment of the Italian Severance Payment (TFR)

Actuarial Fairness or Social Justice?

A Gender Perspective on Redistribution in Pension Systems

Pensions Systems and the Intergenerational Distribution of Resources

What Triggers Early Retirement. Results from Swiss Pension Funds

Le Vieillissement Démographique :

Problématique des Régimes de Pension en Tunisie

A Comparative Analysis of the Costs of Italian Individual Pension Plans

Older Workers and Pensioners: the Challenge of Ageing on the Italian Public Pension System and Labour Market

Risk Aversion and the Utility of Annuities

A Switch Criterion for Defined Contribution Pension Schemes

The Realized Equity Premium has been Higher than Expected: Further Evidence

New Tools in Micromodeling Retirement Decisions: Overview and Applications to the Italian Case

Annuities in Germany before and after the Pension Reform of 2001

Issues in the Regulation of Annuities Markets

The Behaviour of UK Annuity Prices from 1972 to the Present

Valuation of Guaranteed Annuity Conversion Options

Longevity Risk in Living Benefits 


\begin{tabular}{|c|c|c|}
\hline$N^{\circ} 22 / 02$ & $\begin{array}{l}\text { Chris Soares } \\
\text { Mark Warshawsky }\end{array}$ & $\begin{array}{l}\text { Annuity Risk: Volatility and Inflation Exposure in Payments } \\
\text { from Immediate Life Annuities }\end{array}$ \\
\hline$N^{\circ} 21 / 02$ & $\begin{array}{l}\text { Olivia S. Mitchell } \\
\text { David McCarthy }\end{array}$ & Annuities for an Ageing World \\
\hline$N^{\circ} 20 / 02$ & Mauro Mastrogiacomo & Dual Retirement in Italy and Expectations \\
\hline$N^{\circ} 19 / 02$ & $\begin{array}{l}\text { Paolo Battocchio } \\
\text { Francesco Menoncin }\end{array}$ & $\begin{array}{l}\text { Optimal Portfolio Strategies with Stochastic Wage Income and } \\
\text { Inflation: The Case of a Defined Contribution Pension Plan }\end{array}$ \\
\hline$N^{\circ} 18 / 02$ & Francesco Daveri & $\begin{array}{l}\text { Labor Taxes and Unemployment: a Survey of the Aggregate } \\
\text { Evidence }\end{array}$ \\
\hline$N^{\circ} 17 / 02$ & $\begin{array}{l}\text { Richard Disney and } \\
\text { Sarah Smith }\end{array}$ & $\begin{array}{l}\text { The Labour Supply Effect of the Abolition of the Earnings Rule } \\
\text { for Older Workers in the United Kingdom }\end{array}$ \\
\hline$N^{\circ} 16 / 01$ & $\begin{array}{l}\text { Estelle James and } \\
\text { Xue Song }\end{array}$ & $\begin{array}{l}\text { Annuities Markets Around the World: Money’s Worth and Risk } \\
\text { Intermediation }\end{array}$ \\
\hline$N^{\circ} 15 / 01$ & Estelle James & $\begin{array}{l}\text { How Can China Solve ist Old Age Security Problem? The } \\
\text { Interaction Between Pension, SOE and Financial Market Reform }\end{array}$ \\
\hline$N^{\circ} 14 / 01$ & Thomas H. Noe & Investor Activism and Financial Market Structure \\
\hline$N^{\circ} 13 / 01$ & Michela Scatigna & Institutional Investors, Corporate Governance and Pension Funds \\
\hline$N^{\circ} 12 / 01$ & Roberta Romano & $\begin{array}{l}\text { Less is More: Making Shareholder Activism a Valuable } \\
\text { Mechanism of Corporate Governance }\end{array}$ \\
\hline$N^{\circ} 11 / 01$ & $\begin{array}{l}\text { Mara Faccio and Ameziane } \\
\text { Lasfer }\end{array}$ & $\begin{array}{l}\text { Institutional Shareholders and Corporate Governance: The Case } \\
\text { of UK Pension Funds }\end{array}$ \\
\hline$N^{\circ} 10 / 01$ & $\begin{array}{l}\text { Vincenzo Andrietti and Vincent } \\
\text { Hildebrand }\end{array}$ & $\begin{array}{l}\text { Pension Portability and Labour Mobility in the United States. } \\
\text { New Evidence from the SIPP Data }\end{array}$ \\
\hline$N^{\circ} 9 / 01$ & Hans Blommestein & $\begin{array}{l}\text { Ageing, Pension Reform, and Financial Market Implications in } \\
\text { the OECD Area }\end{array}$ \\
\hline$N^{\circ} 8 / 01$ & Margherita Borella & $\begin{array}{l}\text { Social Security Systems and the Distribution of Income: an } \\
\text { Application to the Italian Case }\end{array}$ \\
\hline$N^{\circ} 7 / 01$ & Margherita Borella & $\begin{array}{l}\text { The Error Structure of Earnings: an Analysis on Italian } \\
\text { Longitudinal Data }\end{array}$ \\
\hline$N^{\circ} 6 / 01$ & Flavia Coda Moscarola & $\begin{array}{l}\text { The Effects of Immigration Inflows on the Sustainability of the } \\
\text { Italian Welfare State }\end{array}$ \\
\hline $\mathrm{N}^{\circ} 5 / 01$ & Vincenzo Andrietti & $\begin{array}{l}\text { Occupational Pensions and Interfirm Job Mobility in the } \\
\text { European Union. Evidence from the ECHP Survey }\end{array}$ \\
\hline$N^{\circ} 4 / 01$ & Peter Diamond & Towards an Optimal Social Security Design \\
\hline $\mathrm{N}^{\circ} 3 / 00$ & $\begin{array}{l}\text { Emanuele Baldacci } \\
\text { Luca Inglese }\end{array}$ & $\begin{array}{l}\text { Le caratteristiche socio economiche dei pensionati in Italia. } \\
\text { Analisi della distribuzione dei redditi da pensione (only available } \\
\text { in the Italian version) }\end{array}$ \\
\hline $\mathrm{N}^{\circ} 2 / 00$ & $\begin{array}{l}\text { Pier Marco Ferraresi } \\
\text { Elsa Fornero }\end{array}$ & $\begin{array}{l}\text { Social Security Transition in Italy: Costs, Distorsions and (some) } \\
\text { Possible Correction }\end{array}$ \\
\hline $\mathrm{N}^{\circ} 1 / 00$ & Guido Menzio & Opting Out of Social Security over the Life Cycle \\
\hline
\end{tabular}

